Article

\title{
Neuropeptide S Receptor Stimulation Excites Principal Neurons in Murine Basolateral Amygdala through a Calcium-Dependent Decrease in Membrane Potassium Conductance
}

\author{
Sion Park ${ }^{\dagger}$, Pia Flüthmann ${ }^{\dagger}$, Carla Wolany, Lena Goedecke, Hannah Maleen Spenner, Thomas Budde $\mathbb{}$, \\ Hans-Christian Pape and Kay Jüngling *
}

check for updates

Citation: Park, S.; Flüthmann, P.; Wolany, C.; Goedecke, L.; Spenner, H.M.; Budde, T.; Pape, H.-C.; Jüngling, K. Neuropeptide S Receptor Stimulation Excites Principal Neurons in Murine Basolateral Amygdala through a Calcium-Dependent Decrease in Membrane Potassium Conductance. Pharmaceuticals 2021, 14, 519. https://doi.org/10.3390/ ph14060519

Academic Editors: Chiara Ruzza and Rainer K. Reinscheid

Received: 20 April 2021

Accepted: 18 May 2021

Published: 27 May 2021

Publisher's Note: MDPI stays neutral with regard to jurisdictional claims in published maps and institutional affiliations.

Copyright: (c) 2021 by the authors. Licensee MDPI, Basel, Switzerland. This article is an open access article distributed under the terms and conditions of the Creative Commons Attribution (CC BY) license (https:// creativecommons.org/licenses/by/ $4.0 /)$.
Institute of Physiology I, Westfälische Wilhelms-Universität Münster, Robert-Koch Strasse 27a, 48149 Münster, Germany; sion.park@hotmail.com (S.P.); piafluthmannde@gmail.com (P.F.); carla.v.wolany@icloud.com (C.W.); Lena.Goedecke@web.de (L.G.); hannahspenner@uni-muenster.de (H.M.S.); Thomas.Budde@ukmuenster.de (T.B.); papechris@ukmuenster.de (H.-C.P.)

* Correspondence: kay.juengling@ukmuenster.de

+ These authors contribute equally to this work.

Abstract: Background: The neuropeptide S system, consisting of the 20 amino acid neuropeptide NPS and its G-protein-coupled receptor (GPCR) neuropeptide S receptor 1 (NPSR1), has been studied intensively in rodents. Although there is a lot of data retrieved from behavioral studies using pharmacology or genetic interventions, little is known about intracellular signaling cascades in neurons endogenously expressing the NPSR1. Methods: To elucidate possible G-protein-dependent signaling and effector systems, we performed whole-cell patch-clamp recordings on principal neurons of the anterior basolateral amygdala of mice. We used pharmacological interventions to characterize the NPSR1-mediated current induced by NPS application. Results: Application of NPS reliably evokes inward-directed currents in amygdalar neurons recorded in brain slice preparations of male and female mice. The NPSR1-mediated current had a reversal potential near the potassium reversal potential $\left(\mathrm{E}_{\mathrm{K}}\right)$ and was accompanied by an increase in membrane input resistance. GDP- $\beta-S$ and BAPTA, but neither adenylyl cyclase inhibition nor 8-Br-cAMP, abolished the current. Intracellular tetraethylammonium or 4-aminopyridine reduced the NPS-evoked current. Conclusion: NPSR1 activation in amygdalar neurons inhibits voltage-gated potassium $\left(\mathrm{K}^{+}\right)$channels, most likely members of the delayed rectifier family. Intracellularly, $G_{\alpha q}$ signaling and calcium ions seem to be mandatory for the observed current and increased neuronal excitability.

Keywords: NPSR1; amygdala; potassium conductance; calcium; patch-clamp; mice

\section{Introduction}

The neuropeptide S system, consisting of the 20 amino acid neuropeptide NPS and its G-protein-coupled receptor (GPCR) neuropeptide S receptor 1 (NPSR1) has been identified in the central nervous system of rodents and humans [1,2]. NPS-expressing neurons seem to be largely restricted to distinct brain stem nuclei, located in the pericoerulear region and between the lateral parabrachial and Koelliker-Fuse nucleus in mice [3,4]. In contrast, NPSR1-expressing neurons are found in a variety of regions within the central nervous system of rodents, e.g., olfactory areas, amygdala, frontal and retrosplenial cortex, and midline thalamic regions [3]. Pharmacological studies and use of NPS- or NPSR1-deficient mice point to an important role of the NPS system, e.g., in memory formation [5,6], fear and anxiety [7-10], social behavior [11], addiction [12,13], and arousal/attention [1,5].

GPCR-mediated signaling can be $\mathrm{G}$ protein dependent or, according to more recent concepts, independent [14]. G proteins can be subdivided into four major families: $G_{\mathrm{q} / 11}$, $\mathrm{G}_{\mathrm{S}}, \mathrm{G}_{\mathrm{i} / \mathrm{o}}$, or $\mathrm{G}_{12 / 13}$, all triggering different intracellular signaling cascades when activated [15]. Upon activation, the heterotrimeric $G$ protein dissociates into an $\alpha$ and a $\beta / \gamma$ subunit, each able to modulate intracellular or membrane-located effectors. $G$ protein 
signaling is initiated by the exchange of GDP by GTP, and is terminated when GTP is hydrolyzed to GDP by the $\alpha$ subunit [15]. In addition to G proteins, activated GPCRs can couple to arrestins or G-protein-coupled receptor kinases (GRK), which, in turn, can contribute to intracellular signaling cascades or lead to GPCR desensitization and internalization.

Early studies in HEK and CHO cell lines expressing human or murine NPSR1 showed that NPSR1 activation by its ligand triggers intracellular signaling cascades involving an increase in intracellular calcium levels, formation of cAMP, and MAPK phosphorylation [16-18]. These findings strongly suggest that NPSR1 activation is followed by signaling cascades involving $\mathrm{G}_{\mathrm{q}}$ and $\mathrm{G}_{\mathrm{s}}$. In addition, calcium transients following NPSR1 activation have been observed in neurons, and pharmacological interventions strongly suggest pathways dependent on phospholipase $C$ (PLC), inositol-3-phosphate receptors $\left(\mathrm{IP}_{3} \mathrm{R}\right)$, and ryanodine receptors (RyR) to be involved in NPSR1 signaling [19-21].

Electrophysiological recordings in neuronal slice preparations revealed inward-directed currents, increased neuronal excitability and enhanced synaptic activity following NPSR1 activation [8,21-24]. With few exceptions (e.g., [21]), a link between the observed modulation of ionic currents and the underlying signaling cascades is still largely lacking.

Here we used a straight-forward electrophysiological approach to identify the ionic nature of the NPSR1-mediated current in principal neurons of the anterior basolateral amygdala (aBA PNs), which have been implicated in processes of fear and extinction [24]. We identified putative intracellular signaling pathways following NPSR1 activation, consequently inducing a reduction of $\mathrm{K}^{+}$conductances, and thereby increasing neuronal discharges.

\section{Results}

\subsection{NPS-Induced Inward Currents in NPSR1-Expressing aBA Principal Neurons}

As described previously $[3,8,24]$, we detected NPSR1-coding mRNA predominantly in the anterior part of the basolateral amygdala $(\mathrm{aBA})$ by fluorescence in situ hybridization in mouse brain slices (Figure 1A). A second population of NPSR1-expressing principal neurons (PN) is located in the lateral nucleus of the amygdala (LA; [24]), but the posterior regions of the basolateral nucleus and the central nucleus of the amygdala (CeA) are largely devoid of NPSR1 mRNA. We performed whole-cell voltage-clamp recordings from PNs in coronal slices containing the aBA (Figure 1B) to analyze intracellular signaling cascades following NPSR1 activation by NPS. Application of 50 or $150 \mathrm{nM}$ NPS elicited a transient inward current in aBA PNs (Figure 1C). The overall fraction of NPS-responsive neurons was 85.7 and $91.5 \%$ following 50 or $150 \mathrm{nM}$ NPS, respectively. The current density evoked by $150 \mathrm{nM}$ was significantly larger compared to current densities evoked by $50 \mathrm{nM}(150 \mathrm{nM}$ NPS: $-0.70 \pm 0.09 \mathrm{pA} / \mathrm{pF} ; 50 \mathrm{nM}$ NPS: $-0.42 \pm 0.04 \mathrm{pA} / \mathrm{pF}$; RMANOVA interaction of time and concentration: $\mathrm{F}(2,38)=6.8 ; p=0.003$; Bonferroni post hoc: 150 baseline vs. 150 max: $p=1.3 \times 10^{-11} ; 50$ baseline vs. 50 max: $p=1.3 \times 10^{-5}$; 150 max vs. 50 max: $p=0.032$; Figure 1D,E). Since male and female mice were used, we analyzed the current density in both sexes in a separate set of experiments (Figure 1F,G). Neither the time course nor the maximal current density differed between male and female mice (males: $-0.657 \pm 0.09 \mathrm{pA} / \mathrm{pF} ; n=11$; females: $-0.656 \pm 0.05 \mathrm{pA} / \mathrm{pF} ; n=8$; $t$-test: $t=-0.09 ; \mathrm{df}=17 ; p=0.926)$. In the following, data from both sexes were pooled. During voltage-clamp recordings, the input resistance of the cell was monitored by applying brief voltage steps ( $-5 \mathrm{mV} ; 50 \mathrm{~ms}$ duration) in each recorded sweep (10 s duration). Under baseline conditions, the input resistance was $167 \pm 6 \mathrm{M} \Omega$, and increased significantly in the presence of $150 \mathrm{nM} \mathrm{NPS}$ to $208 \pm 8 \mathrm{M} \Omega$ (paired $t$-test: $t=-7.82 ; \mathrm{df}=36 ; p=2.8 \times 10^{-9}$; $n=37)$. 


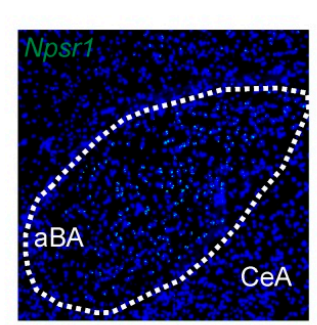

D

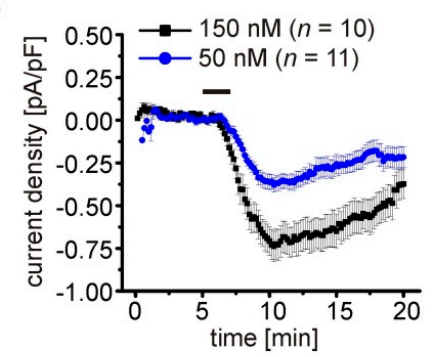

$\mathrm{H}$

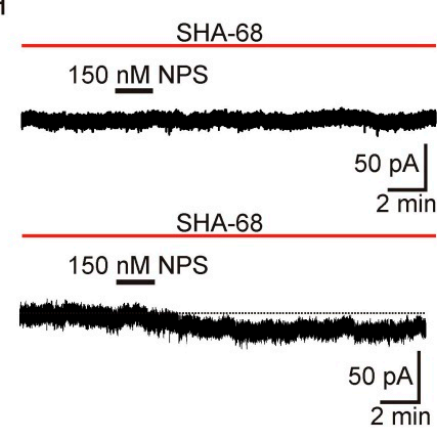

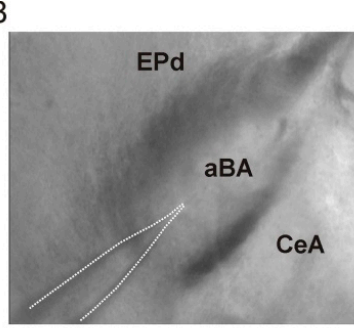

E

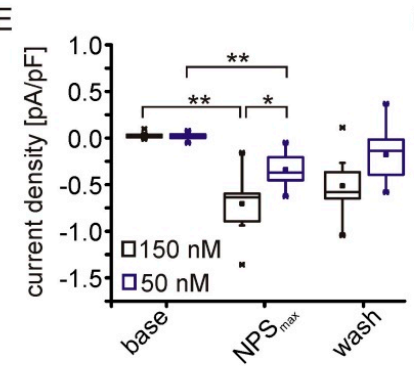

।

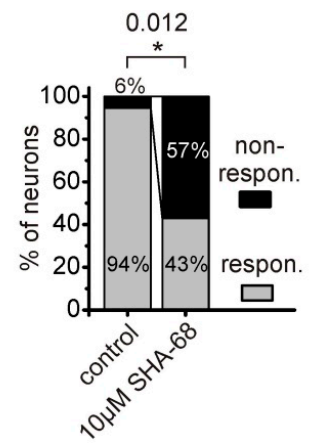

$J$
C

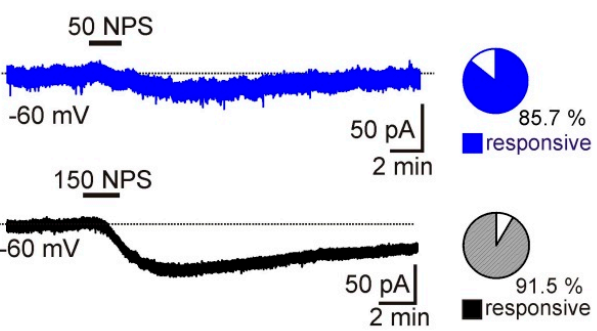

F 0.5
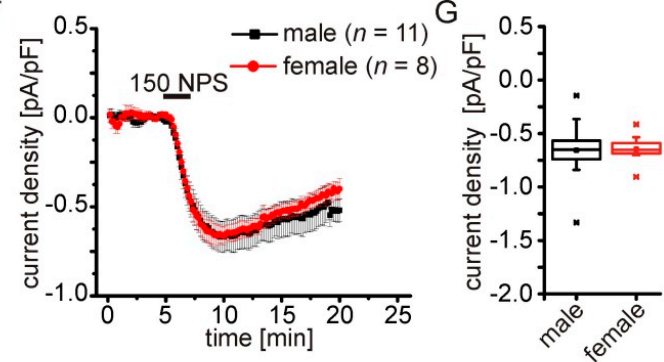

$\mathrm{K}$

$\longrightarrow$ - control $(n=17)$
$\rightarrow$ SHA-68 $(n=3$ of 7 recorded)
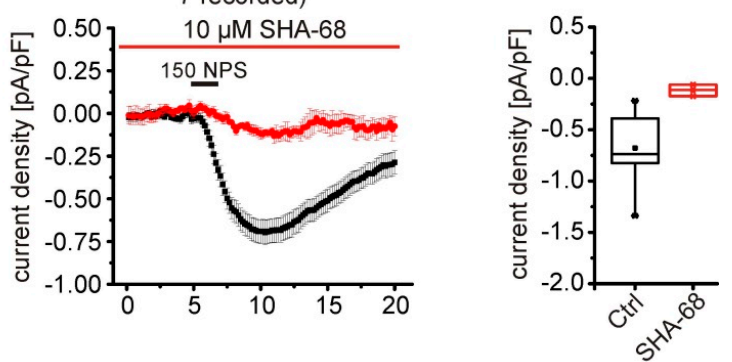

Figure 1. NPS-induced inward current in NPSR1-expressing aBA principal neurons. (A) Npsr1 mRNA (green) detection in neurons of the aBA by fluorescence in situ hybridization. DAPI (blue) was used to mark cellular nuclei. The medially located central nuclei of the amygdala (CeA) are devoid of Npsr1 mRNA. (B) Example of a coronal slice preparation used for electrophysiological recordings of aBA PNs. The white lines delineate the recording pipette. (C) Examples of membrane currents recorded from aBA PNs at a holding potential of $-60 \mathrm{mV}$. NPSR1-dependent inward-directed currents were elicited by application of $50 \mathrm{nM}$ (blue) or $150 \mathrm{nM}$ (black) NPS. Pie charts show the overall fraction of NPS-responsive neurons during application of 50 or 150 nM NPS. (D) Time course of mean current densities elicited by 50 (blue) or 150 nM (black) NPS. NPS was applied for $2.5 \mathrm{~min}$. (E) Quantification of recorded current densities following application of either 50 or $150 \mathrm{nM}$ NPS. The maximal current densities are concentration dependent. (F) Time course of the NPS-induced current recorded in aBA PNs in slices from male and female mice. No sex-dependent differences were detected in the time course or in the maximal current densities (G). (H) Examples of $150 \mathrm{nM}$ NPS application in the presence of the NPSR1 antagonist SHA-68 $(10 \mu \mathrm{M})$. Examples depict nonresponsive (upper trace) and responsive neurons (lower trace). (I) Fraction of responsive aBA PNs in the presence of SHA-68 and during control conditions. (J) Mean time course of responsive neurons in the presence of SHA-68 $(n=3)$ and during control recordings. $(\mathbf{K})$ In the presence of SHA-68, the maximal current density was significantly reduced. ${ }^{*} p<0.05 ;{ }^{* *} p<0.01$.

To test the specificity of our approach, we applied NPS in the presence of the NPSR1specific antagonist SHA-68 ([25]; Figure 1H). The fraction of non-responsive neurons significantly increased to $57 \%$ in the presence of SHA-68, compared to $6 \%$ under control conditions (Fisher's exact test: $p=0.012$; Figure 1I). Only three of the recorded aBA PNs showed a detectable inward current upon NPS application, which was significantly decreased compared to controls (control: $-0.679 \pm 0.07 \mathrm{pA} / \mathrm{pF} ; n=17$; SHA-68: $-0.116 \pm 0.032$; $n=3$; $t$-test: $t=-3.28$; $\mathrm{df}=18 ; p=0.004$; Figure $1 \mathrm{~J}, \mathrm{~K})$. These data substantiate the evidence that NPSR1 activation by NPS induces a transient inward-directed current in aBA 
PNs of male and female mice. In this way, NPS could excite the neurons and activate amygdala networks.

\subsection{The NPSR1-Dependent Current Results from Reduced Potassium Conductances}

To characterize the nature of the NPSR1-mediated current, hyper- and depolarizing voltage steps with increasing amplitudes were applied from a holding potential of $-60 \mathrm{mV}$ (Figure 2A). The NPS-induced current was calculated at each voltage step by subtraction of the current obtained during baseline. Amplitudes of the instantaneous current at the beginning and the steady state current at termination of the voltage step were analyzed, and the calculated NPS-induced current was plotted against the respective step potential (Figure 2B). The reversal potential of the NPSR1-mediated current was $-101.5 \pm 0.8 \mathrm{mV}$ $(n=4)$ for steady state currents and, thus, was close to the calculated $\mathrm{K}^{+}$reversal potential $\left(\mathrm{E}_{\mathrm{K}}\right)$ of $-109 \mathrm{mV}$. To confirm these findings, hyperpolarizing voltage-clamp ramps were performed from $0 \mathrm{mV}$ to $-120 \mathrm{mV}$ in $250 \mathrm{~ms}$ (Figure 2C). The NPS-induced current calculated by subtraction of ramp $p_{N P S}-$ ramp baseline had a reversal potential of $-101.2 \pm 2.8 \mathrm{mV}(n=3)$, again close to $\mathrm{E}_{\mathrm{K}}$ (Figure 2D). Therefore, we reasoned that the NPSR1-mediated inward current is due to a reduction of a $\mathrm{K}^{+}$conductance. Therefore, reducing the electrochemical gradient for $\mathrm{K}^{+}$should affect the amplitude of the NPSR1-mediated current recorded at $-60 \mathrm{mV}$. We shifted $\mathrm{E}_{\mathrm{K}}$ from $-109 \mathrm{mV}$ to $-73.5 \mathrm{mV}$ by increasing extracellular $\mathrm{K}^{+}$from 2.5 to $10 \mathrm{mM}$, thereby decreasing the electrochemical driving force from approximately $-49 \mathrm{mV}$ to $-13.5 \mathrm{mV}$. The current density of the NPS-induced current was reduced to $-0.23 \pm 0.05 \mathrm{pA} / \mathrm{pF}(n=6)$ in $10 \mathrm{mM} \mathrm{K}^{+}$, and was significantly smaller than under control conditions (control: $-0.668 \pm 0.06 \mathrm{pA} / \mathrm{pF} ; n=15 ; t$-test: $t=-4.31 ; \mathrm{df}=19 ; p=3.8 \times 10^{-4}$; Figure 2E,F).

A

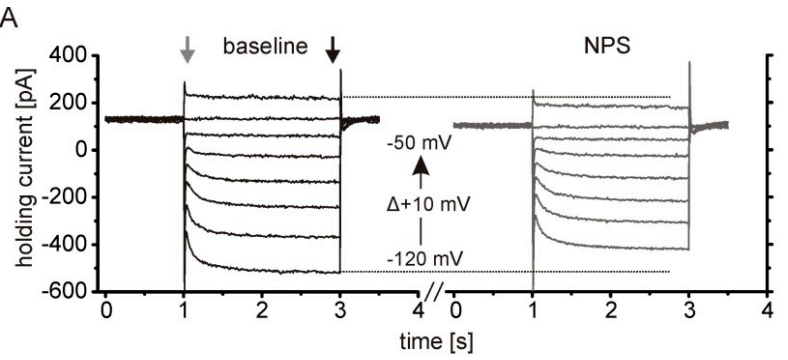

C

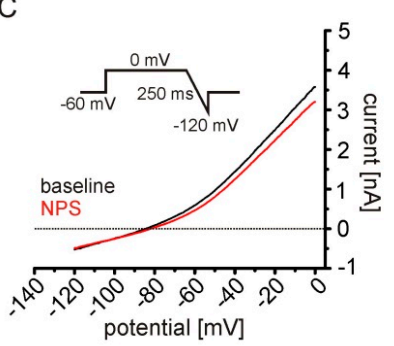

D

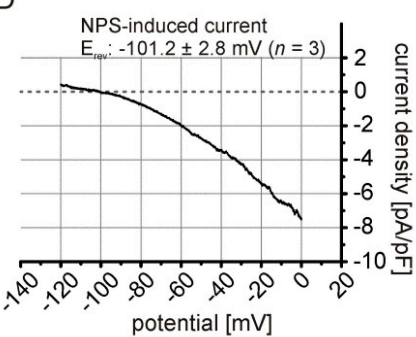

B

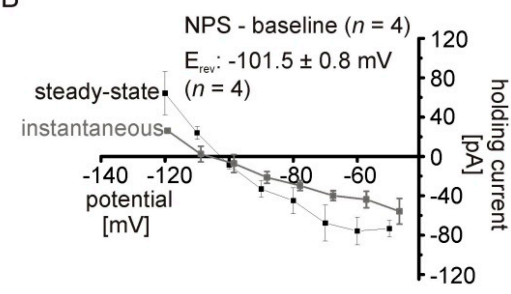

E

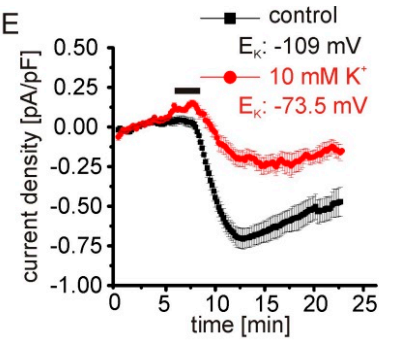

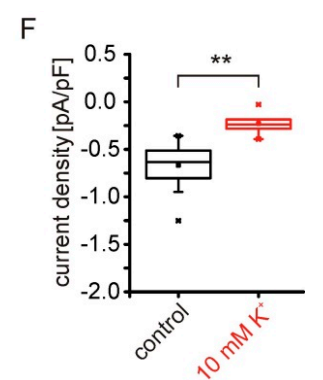

Figure 2. The NPSR1-dependent current results from reduced potassium conductances. (A) Voltage steps ( $-120 \mathrm{mV}$ to $-50 \mathrm{mV} ; \Delta+10 \mathrm{mV} ; 2 \mathrm{~s}$ duration) from a holding potential of $-60 \mathrm{mV}$ in the voltage-clamp mode. Recordings were done under baseline conditions and in the presence of $150 \mathrm{nM}$ NPS. For both conditions, baseline and in the presence of NPS, the steady-state current (black arrow) and the instantaneous current (grey arrow) were analyzed. (B) Plot of the I-V curves calculated from step protocols. The NPS-induced current was calculated as: current $_{\text {NPS-current }}$ baseline $_{\text {(C) Example of }}$ hyperpolarizing ramp recordings $(0 \mathrm{mV}$ to $-120 \mathrm{mV} ; 250 \mathrm{~ms})$ from aBA PNs during baseline conditions (black) and in the presence of $150 \mathrm{nM}$ NPS (red). (D) Mean NPS-induced current calculated from three recordings. The resultant current was calculated: current $\mathrm{NPS}$-current baseline $_{\text {. }}$ (E) Time course of the NPS-induced current during control conditions (black), and with elevated potassium concentration $\left(10 \mathrm{mM}\right.$; red) in the ACSF. (F) In the presence of $10 \mathrm{mM} \mathrm{K}^{+}$, the NPS-induced current is significantly reduced compared to control conditions. ${ }^{* *} p<0.01$. 


\subsection{The NPS-Induced Current Is Dependent on NPSR1-G $\alpha$-Signaling}

Activation of the NPSR1 by its ligand NPS triggers intracellular signaling pathways via $\mathrm{G}_{\alpha q}$ and/or $\mathrm{G}_{\alpha \mathrm{s}}$ proteins, as shown in HEK and CHO cells expressing the receptor $[1,17,19]$. In contrast, the contribution of $\mathrm{G}$ protein activity to the induction of the inward current observed here is still unknown. To test the significance of $G$ protein signaling, voltageclamp recordings in the presence of $2 \mathrm{mM} \mathrm{GDP}-\beta-\mathrm{S}$ were performed (Figure 3A). GDP- $\beta-\mathrm{S}$ blocks the activation of $G$ proteins by inhibiting binding of GTP to $G$ proteins [26]. Adding $2 \mathrm{mM}$ GDP- $\beta-S$ to the intracellular solution prevented responses to $50 \mathrm{nM}$ NPS in aBA PNs (Figure 3B). Only one of six recorded neurons did show a detectable inward current (Figure 3E). To quantify these findings, only here we averaged recorded currents of responsive and non-responsive neurons in the presence and absence of GDP- $\beta$-S. Statistical comparison revealed a significant reduction of mean current densities (RM ANOVA: interaction treatment $x$ time: $\mathrm{F}(2,40)=3.93 ; p=0.028$; Bonferroni post hoc test: $\mathrm{NPS}_{\max }$ control vs. $\mathrm{NPS}_{\max }$ GDP- $\beta$-S: $p=0.034$; baseline control vs. NPS ${ }_{\max }$ control: $p=8.5 \times 10^{-7}$; baseline control vs. wash control: $p=0.006$; Figure $3 \mathrm{~B}, \mathrm{C}$ ) and a significantly reduced fraction of responsive neurons (Fisher's exact test: $p=0.005$; Figure 3E). Application of $150 \mathrm{nM}$ NPS induced a current in $86 \%$ of the recorded neurons in the presence of GDP- $\beta$-S (Figure 3E), while the mean current density was significantly reduced to $-0.08 \pm 0.04 \mathrm{pA} / \mathrm{pF}$ in these neurons $(n=6$; Figure $3 \mathrm{H})$. Next, we used gallein $(50 \mu \mathrm{M})$ to inhibit $\mathrm{G}_{\beta \gamma}$ signaling in aBA PNs during application of $150 \mathrm{nM}$ NPS (Figure 3F). Although a trend was observed, the mean current densities were not significantly reduced in the presence of gallein (gallein: $-0.48 \pm 0.07 \mathrm{pA} / \mathrm{pF} ; n=10$; control: $-0.667 \pm 0.07 ; n=17$; one-way ANOVA: $\mathrm{F}(2,30)=9.71$; $p=5.5 \times 10^{-4}$; Bonferroni post hoc test: control vs. GDP- $\beta$-S: $p=4.1 \times 10^{-4}$; gallein vs. GDP- $\beta$-S: $p=0.047$; Figure $3 \mathrm{G}, \mathrm{H})$. These data strongly suggest that mostly $\mathrm{G}_{\alpha}$ signaling following NPSR1 activation in aBA PNs mediates the NPS-induced current.

\subsection{The NPSR1-Mediated Current Depends on Rise of Intracellular Calcium Concentrations}

According to previous publications, NPSR1 activation increases intracellular calcium and cAMP concentrations via $G_{\alpha q}$ and $G_{\alpha s}$ signaling [1,19]. In order to test the contribution of these signaling cascades to the observed current, we performed voltage-clamp experiments in the presence of 2-APB (Figure 4A). 2-APB has been reported to inhibit inositol-3-phosphate receptors $\left(\mathrm{IP}_{3} \mathrm{R}\right)$ in the endoplasmic reticulum (ER), store-operated calcium-entry (SOCE), and a subset of transient receptor potential channels (TRP) in a concentration-dependent manner, but can activate TRPV1, TRPV2, and TRPV3 [27-29]. We have shown previously that 2-APB $(25 \mu \mathrm{M})$ abolishes NPS-induced calcium transients in cultured hippocampal neurons expressing human NPSR1 [19]. Here, $50 \mu \mathrm{M}$ 2-APB significantly reduced the current induced by $150 \mathrm{nM}$ NPS in aBA PNs of the mouse amygdala (2-APB: $-0.219 \pm 0.032 \mathrm{pA} / \mathrm{pF} ; n=7$; control: $-0.667 \pm 0.07 \mathrm{pA} / \mathrm{pF} ; n=17$; U-Test: $\mathrm{U}=4 ; \mathrm{Z}=-3.493 ; p=0.001$; Figure 4B,D). Next, we included $10 \mathrm{mM}$ BAPTA in the recording pipette to buffer cytosolic calcium (Figure 4A,C). BAPTA significantly reduced the NPSR1-mediated current in PNs (BAPTA: $-0.256 \pm 0.07 \mathrm{pA} / \mathrm{pF} ; n=11$; control: $-0.679 \pm 0.07 \mathrm{pA} / \mathrm{pF} ; n=17$; U-test: $\mathrm{u}=18 ; \mathrm{z}=-3.53 ; p=4.2 \times 10^{-4}$; Figure $\left.4 \mathrm{C}, \mathrm{D}\right)$. These findings indicate the involvement of intracellular $\mathrm{G}_{\alpha q}$-dependent $\mathrm{Ca}^{2+}$ signaling following NPSR1 activation.

Next, we tested the possible role of $G_{\alpha s}$ signaling by inhibiting adenylyl cyclase activity with SQ 22536 ([30]; $90 \mu \mathrm{M}$; Figure 4E,F). SQ 22536 had no effect on the NPSR1mediated current elicited by $150 \mathrm{nM}$ NPS (SQ22536: $-0.601 \pm 0.068 \mathrm{pA} / \mathrm{pF} ; n=6$; control: $-0.667 \pm 0.07 \mathrm{pA} / \mathrm{pF} ; n=17 ;$ Figure $4 \mathrm{~F}, \mathrm{H})$. In addition, adding $100 \mu \mathrm{M} 8$-Br-cAMP to the intracellular recording solution to occlude potential NPSR1-dependent cAMP-signaling had no effect on the NPS-evoked current (8-Br-cAMP: $-0.504 \pm 0.056 \mathrm{pA} / \mathrm{pF} ; n=14$; one-Way ANOVA control vs. SQ 22536 vs. 8-Br-cAMP: F $(2,34)=1.71 ; p=0.195 ;$ Figure $4 \mathrm{H}$ ). These data indicate that the NPSR1-mediated inward current depends on intracellular $\mathrm{Ca}^{2+}$ signaling pathways, with no involvement of cAMP-dependent mechanisms. 
A
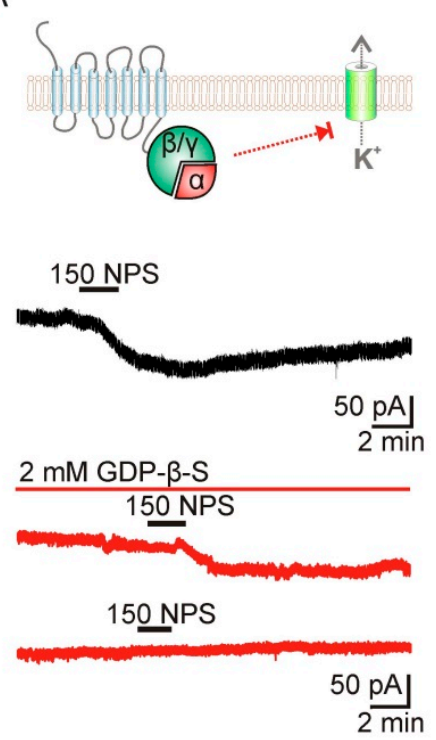

F

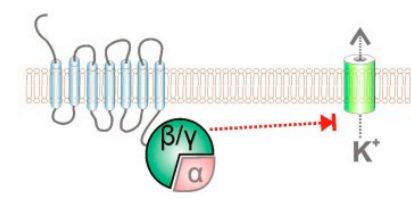

Gallein

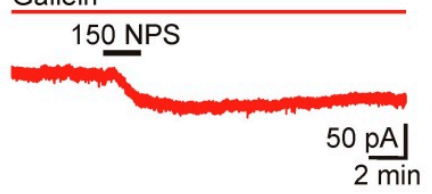

B
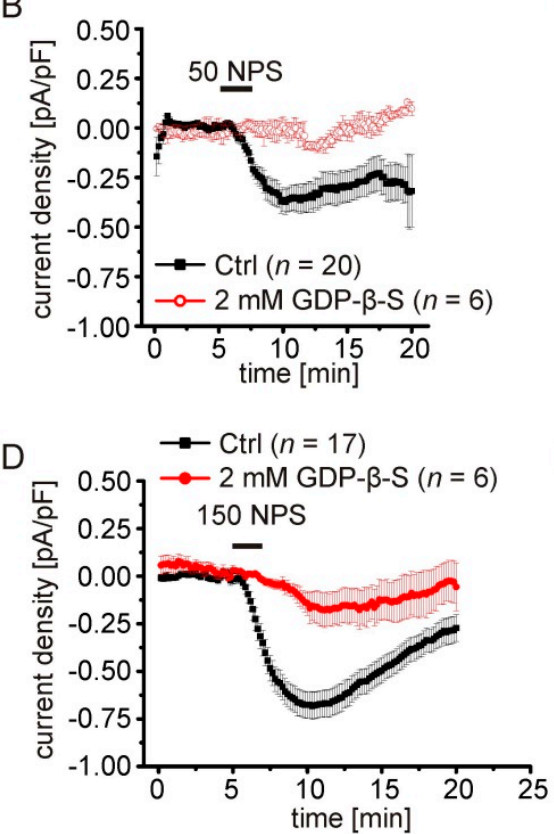

G

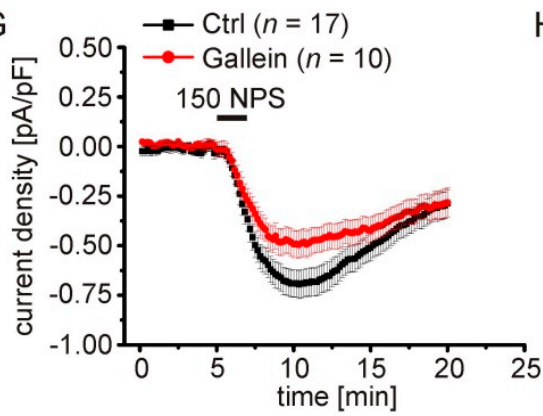

C
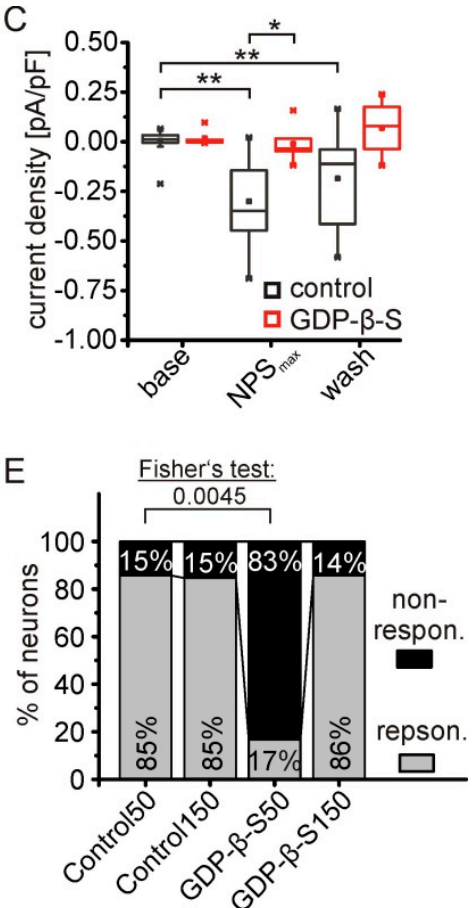

$\mathrm{H}$

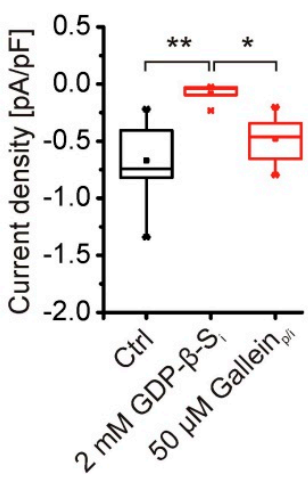

Figure 3. The NPS-induced current is dependent on NPSR1-G $\alpha$-signaling. (A) To differentiate between G-protein-dependent and direct GPCR-effector interactions leading to changes of potassium conductances, GDP- $\beta$-S was used to inhibit intracellular $\mathrm{G}$ protein signaling. Example traces show the NPS-induced current during control conditions and with $2 \mathrm{mM}$ GDP- $\beta$-S in the intracellular solution. Examples of responding and nonresponding neurons are depicted. (B) Time course of mean current densities during control conditions, and in the presence of GDP- $\beta$-S. NPS ( $50 \mathrm{nM}$ ) was bath applied for $2.5 \mathrm{~min}$. Of note, the mean current density in the presence of GDP- $\beta-S$ was calculated from responsive and nonresponsive neurons, since $50 \mathrm{nM}$ NPS elicited a detectable current in only one of six recorded neurons (E). For comparison, nonresponsive neurons of the control were included in the analysis here. (C) Statistical analysis reveals a lack of effect in GDP- $\beta$-S treated neurons upon application of 50 nM NPS. (D) Time course of mean current densities during control recordings, and in presence of $2 \mathrm{mM}$ GDP- $\beta$-S. NPS (150 nM) was applied for $2.5 \mathrm{~min}$. (E) Fractions of responsive and nonresponsive neurons during control conditions ( $50 \mathrm{nM}$ or $150 \mathrm{nM}$ NPS), and in the presence of GDP- $\beta-\mathrm{S}$ (50 nM or $150 \mathrm{nM}$ NPS). In the presence of GDP- $\beta-S, 50$ nM NPS fails to evoke a detectable current compared to control conditions. (F) To test for a possible role of the $\mathrm{G} \beta / \gamma$-subunits, the subunit-specific inhibitor gallein $(50 \mu \mathrm{M})$ was used. Example trace shows an NPS-evoked current in the presence of gallein. (G) Time course of NPS-dependent currents during control conditions, and in presence of $50 \mu \mathrm{M}$ gallein. (H) Quantification of mean maximal current densities evoked by $150 \mathrm{nM}$ NPS in the presence of GDP- $\beta$-S or gallein compared to the control. ${ }^{*} p<0.05 ;{ }^{* *} p<0.01$. 
A
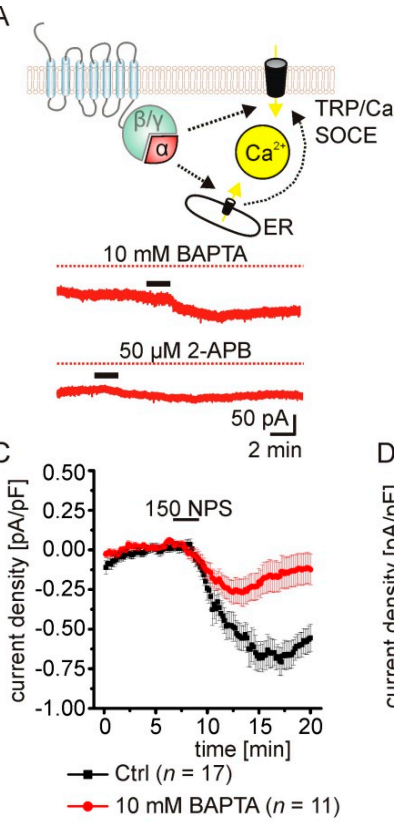

E

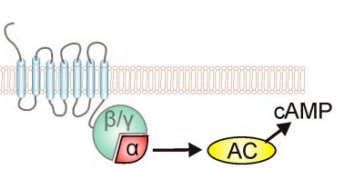

$90 \mu \mathrm{M} \mathrm{SQ} 22536$

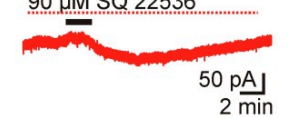

100 4 M 8-Br-CAMP
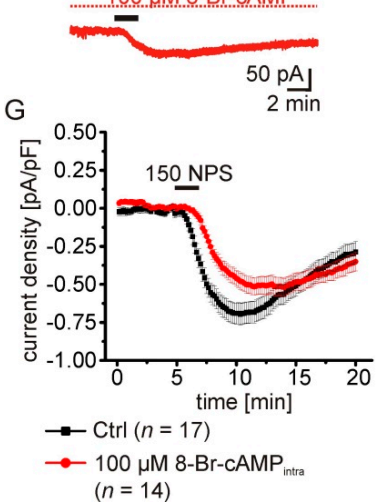

B
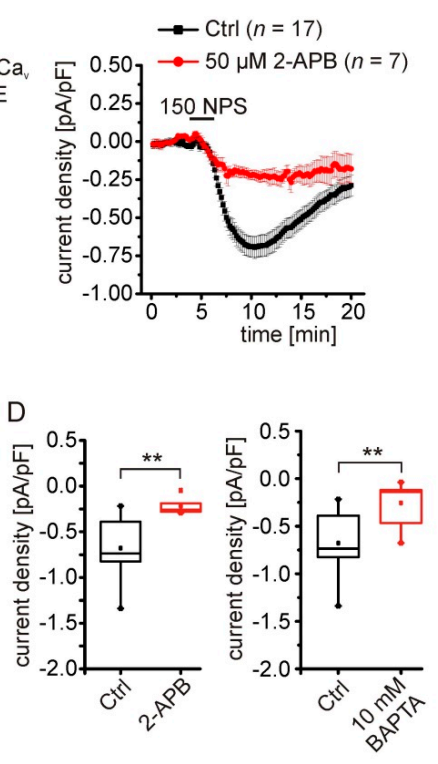

F

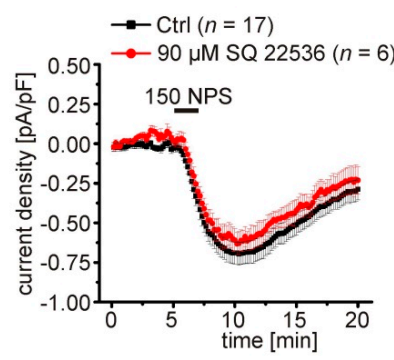

$\mathrm{H}$

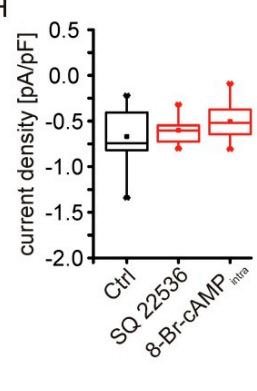

Figure 4. The NPSR1-mediated current depends on a rise of intracellular calcium concentration. (A) Activation of the NPSR1 might trigger intracellular signaling cascades leading to a rise of the cytosolic calcium concentration. Putative calcium sources might be the endoplasmic reticulum (ER) or the extracellular space, with TRP channels or store-operated calcium entry (SOCE) as possible routes. (B) The transient NPS-induced current is reduced in the presence of $50 \mu \mathrm{M} 2-\mathrm{APB}$ in the ACSF, and during recordings with $10 \mathrm{mM}$ BAPTA in the intracellular solution (C). (D) The maximal current density in the presence of 2-APB was significantly smaller compared to control conditions. Buffering cytosolic calcium with $10 \mathrm{mM}$ BAPTA significantly reduced the NPSR1-mediated current. (E) Following NPSR1 activation, G $\alpha$ s signaling might trigger cAMP synthesis via adenylyl cyclases (AC). cAMP-dependent kinases might contribute to the observed NPS-dependent current via modulation of potassium conductances. Depicted are example current traces recorded in the presence of AC inhibitor SQ $22536(90 \mu \mathrm{M}$; upper trace) or recorded with $100 \mu \mathrm{M} 8$-Br-cAMP in the internal solution (lower trace). Neither SQ 22536 (F) nor 8-Br-cAMP (G) significantly altered the NPS-evoked inward current. (H) Quantification of the maximal current density recorded during control conditions, and in the presence of SQ 22536 or 8-Br-cAMP. No statistically significant changes were observed. ${ }^{* *} p<0.01$. 


\subsection{Pharmacological Characterization of the NPSR1-Modulated $\mathrm{K}^{+}$Conductance}

In the next series of experiments, we further characterized the $\mathrm{K}^{+}$conductance evoked by NPSR1 stimulation. We applied tetraethyl-ammonium $(10 \mathrm{mM})$ via the ACSF to inhibit a broad spectrum of delayed-rectifier $\mathrm{K}^{+}$channels, XE991 $(20 \mu \mathrm{M})$ to inhibit Mcurrents generated by members of the KCNQ channel family, and $\mathrm{BaCl} 2(0.5 \mathrm{mM})$ to inhibit classes of inward-rectifier and G-protein-dependent inward-rectifier $\left(\mathrm{G}_{\mathrm{irk}}\right) \mathrm{K}^{+}$channels (Figure 5A,C). None of these extracellularly applied compounds inhibited the NPSR1mediated current upon application of $150 \mathrm{nM}$ NPS. However, using a cesium-based intracellular solution containing $10 \mathrm{mM}$ TEA significantly reduced the NPS-elicited current (Csintra $:-0.257 \pm 0.04 \mathrm{pA} / \mathrm{pF} ; n=8$; control: $-0.703 \pm 0.09 \mathrm{pA} / \mathrm{pF} ; n=11$; Figure $5 \mathrm{~B}, \mathrm{C})$. To differentiate between inhibition of $\mathrm{K}^{+}$channels by cesium or intracellular TEA, we used a $\mathrm{K}^{+}$-gluconate-based recording solution containing $10 \mathrm{mM}$ TEA. Intracellular TEA alone reduced the NPSR1-mediated current significantly (K-gluc-TEA intra $_{1}:-0.264 \pm 0.04 \mathrm{pA} / \mathrm{pF}$; $n=16$; control: $-0.703 \pm 0.09 \mathrm{pA} / \mathrm{pF} ; n=11$; Figure $5 \mathrm{~B}, \mathrm{C})$.
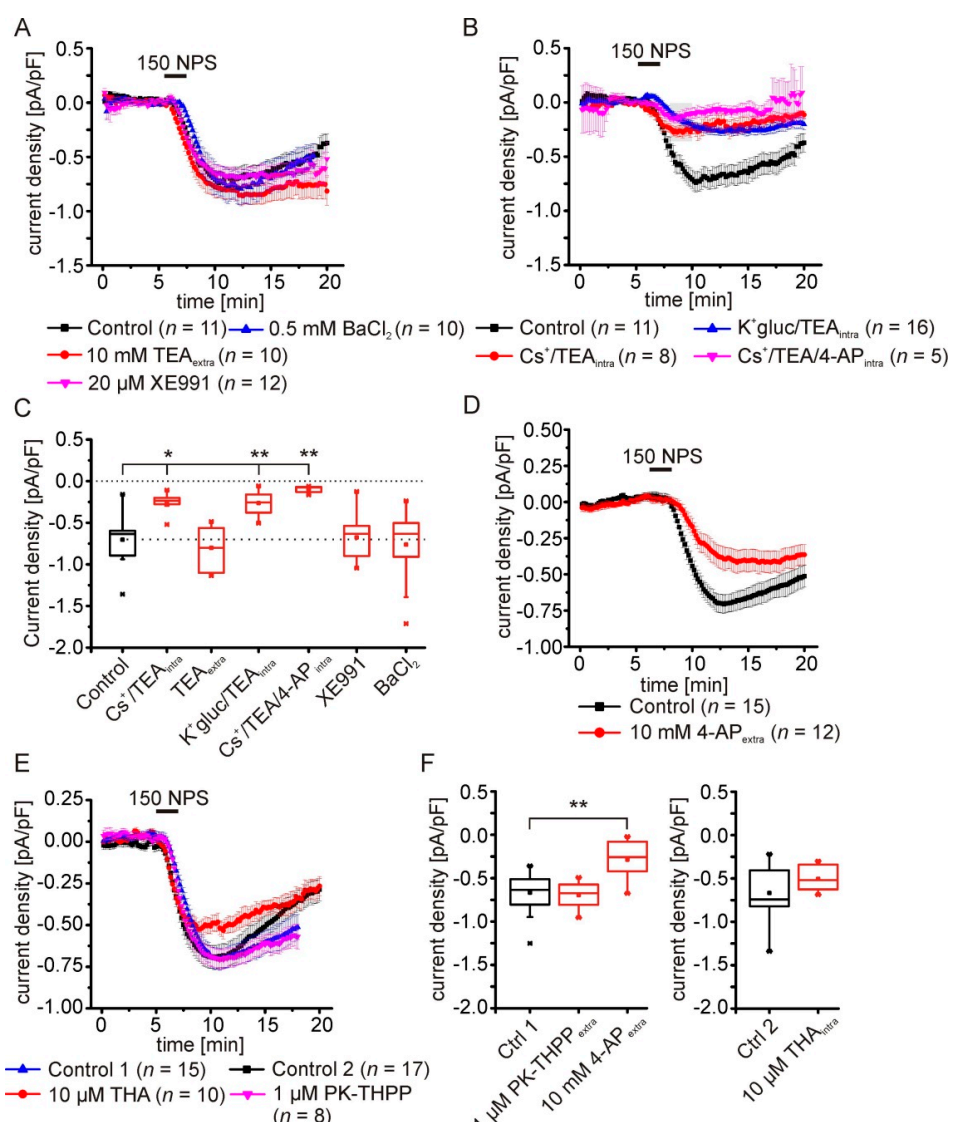

Figure 5. Pharmacological characterization of NPSR1-modulated potassium conductances. (A) Neither the time course nor the maximal amplitude of the NPSR1-mediated current elicited by $150 \mathrm{nM}$ NPS are altered by $0.5 \mathrm{mM} \mathrm{BaCl}_{2}, 10 \mathrm{mM}$ extracellular TEA, or $20 \mu \mathrm{M}$ XE991. (B) The NPSR1-mediated current is sensitive to intracellular recording solutions containing: $\mathrm{K}^{+}$-gluconate and $10 \mathrm{mM}$ TEA (blue), $\mathrm{Cs}^{+}$-methylsulfonate and $10 \mathrm{mM}$ TEA (red), and $\mathrm{Cs}^{+}$-methylsulfonate, $10 \mathrm{mM}$ TEA, and $10 \mathrm{mM}$ 4-AP (magenta). (C) Quantification of the mean current densities depicted in (A) and (B). (D) In the presence of $10 \mathrm{mM} 4-\mathrm{AP}$, the mean current density of the NPSR1-mediated current is significantly attenuated. (E) Intracellular THA $(10 \mu \mathrm{M})$ or extracellular PK-THPP $(1 \mu \mathrm{M})$ do not affect the NPSR1-mediated current. (F) Quantification of the current densities depicted in D) and E). $10 \mathrm{mM}$ 4-AP, but not PK-THPP, significantly reduces the NPSR1-mediated current (one-way ANOVA: $\mathrm{F}(2,32)=12.57 ; p=9.3 \times 10^{-5}$; post hoc test: 4 -AP vs. ctrl 1: $\left.p=2.5 \times 10^{-4}\right)$. Intracellular THA $(10 \mu \mathrm{M})$ does not significantly affect the NPSR1-mediated current $(t$-test: $t=-1.67 ; \mathrm{df}=25 ; p=0.107)$. ${ }^{*} p<0.05 ;{ }^{* *} p<0.01$. 
In order to achieve additional inhibition of TEA-resistant $\mathrm{K}^{+}$channels, i.e., channels contributing to transient outward currents (KCND1-3), we next used a cesium-based intracellular solution containing TEA and 4-aminopyridine. Using this intracellular solution, the NPSR1-mediated current was barely detectable (Cs/TEA/4-AP: $-0.101 \pm 0.02 \mathrm{pA} / \mathrm{pF} ; n=5$; control: $-0.703 \pm 0.09 \mathrm{pA} / \mathrm{pF} ; n=11$; one-way ANOVA: $\mathrm{F}(6,65)=10.56 ; p=3.7 \times 10^{-8}$; post hoc test: control vs. Cs+/TEA intra $p=0.013$; control vs. $\mathrm{K}^{+}$-gluc/TEA intra $p=0.002$; control vs. $\mathrm{Cs}+/ \mathrm{TEA} / 4-\mathrm{AP}_{\text {intra }} p=0.002$; Figure $\left.5 \mathrm{~B}, \mathrm{C}\right)$. Next, recordings with a $\mathrm{K}^{+}$-gluconatebased solution were performed in ACSF containing $10 \mathrm{mM}$ 4-AP. 4-AP alone reduced the NPSR1-mediated current significantly to $-0.286 \pm 0.067 \mathrm{pA} / \mathrm{pF}(n=12)$ compared to controls $(-0.668 \pm 0.061 \mathrm{pA} / \mathrm{pF} ; n=15 ;$ Figure 5D,F $)$.

In a final series, we tested inhibitors of TASK channels that belong to the two-pore domain $\mathrm{K}^{+}$channel (K2P) family. Neither intracellular $10 \mu \mathrm{M}$ tetrahexylammonium chloride (THA), nor extracellular PK-THPP (1 $\mu \mathrm{M}$; TASK1/3-specific) did modulate the NPSR1mediated current significantly (PK-THPP: $-0.695 \pm 0.056 ; n=8$; control 1: $-0.668 \pm 0.061$; $n=15$; THA: $0.504 \pm 0.045 \mathrm{pA} / \mathrm{pF} ; n=10$; control 2: $-0.669 \pm 0.071 ; n=17$; Figure 5E,F). Our detailed characterization revealed that the NPSR1-mediated current is sensitive to intracellular TEA and 4-AP, indicative for voltage-gated potassium channels.

\subsection{NPSR1 Activation Enhances Action Potential Generation in aBA PNs}

NPSR1-dependent reduction of $\mathrm{K}^{+}$conductances likely affects the excitability of aBA PNs. To test this possibility, we performed current-clamp recordings during baseline conditions and during near-maximal NPS effects (Figure 6A). Passive and active membrane properties were analyzed by injecting hyper- and depolarizing rectangular current pulses (500 ms duration), with step-wise (+20 pA) increases in amplitude from a membrane potential of either -80 or $-60 \mathrm{mV}$. The mean resting membrane potential of aBA PNs was at $-75 \pm 1 \mathrm{mV}$, and the mean membrane capacitance was $64 \pm 5 \mathrm{pF}(n=14)$. Next, hyperpolarizing currents were injected from a membrane potential of $-80 \mathrm{mV}$. The input resistance during control and in the presence of NPS was calculated from the slope of the $\mathrm{I}-\mathrm{V}$ plots $\left(\mathrm{R}_{\mathrm{in}}=\Delta \mathrm{U} / \Delta \mathrm{I}\right)$. Although the change of the membrane potential in response to hyperpolarizing current injections from $-80 \mathrm{mV}$ was not significantly different in the presence and absence of NPS (Figure 6B), the calculated input resistance was significantly enhanced in the presence of NPS. $R_{\text {in }}$ was $132 \pm 12 \mathrm{M} \Omega$ during control conditions, and increased to $153 \pm 14 \mathrm{M} \Omega$ in the presence of NPS (paired $t$-test: $t=-4.56 ; \mathrm{df}=9 ; p=0.001$ ). In addition, action potential generation in response to depolarizing currents was enhanced in the presence of NPS (RM-ANOVA: interaction treatment $x$ current $\mathrm{F}(6108)=4.87 ; p=1.9 \times 10^{-4}$; LSD post hoc test: baseline vs. NPS 120 pA: $p=0.042 ; 140$ pA $p=0.035 ; 160$ pA $p=0.006$; 180 pA $p=0.002 ; n=10$; Figure $6 \mathrm{C}$ ). Concomitantly, we observed a negative shift of the action potential threshold during NPSR1 application, while other active membrane properties were unchanged (threshold ${ }_{\text {control }}$ vs. threshold ${ }_{\mathrm{NPS}}$ : paired $t$-test: $t=2.63$; $\mathrm{df}=9$; $p=0.027 ; n=10$; Figure $6 \mathrm{~F}$ ).

Furthermore, we observed significant effects of NPS application for hyperpolarizing current injections at $-60 \mathrm{mV}$. Larger changes of the membrane potential in the presence of NPS were found, thereby indicating an increase in the input resistance (RM-ANOVA interaction treatment $x$ current $\mathrm{F}(5,130)=4.29 ; p=0.001$; LSD post hoc test: baseline vs. NPS: -100 pA $p=0.01 ;-80$ pA $p=0.003 ;-60$ pA $p=0.021 ;-40$ pA $p=0.01 ; n=14$; Figure 6D). The mean input resistance calculated from the I-V plots was $192 \pm 12 \mathrm{M} \Omega$ during baseline conditions, and increased to $268 \pm 24 \mathrm{M} \Omega$ in the presence of NPS (paired $t$-test: $t=-3.061 ; \mathrm{df}=13 ; p=0.009 ; n=14)$. In contrast, NPS failed to significantly increase neuronal discharges in response to depolarizing current injections at $-60 \mathrm{mV}$ (RM-ANOVA: treatment vs. current $\mathrm{F}(7175)=1.25 ; p=0.28 ; n=14$; Figure $6 \mathrm{E}$ ). These data show that NPSR1 activation enhances neuronal discharges, accompanied by a reduction of the action potential threshold and a moderate increase of input resistance. 
A

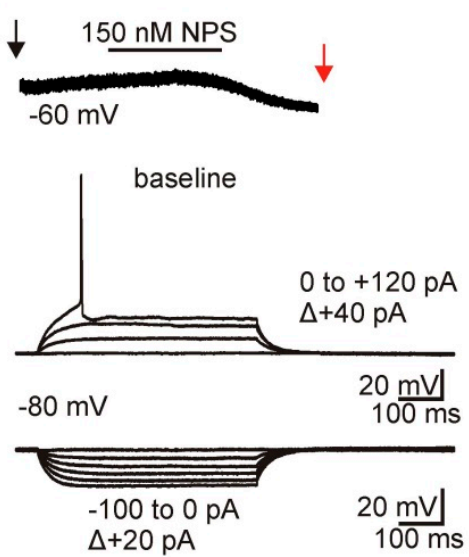

NPS

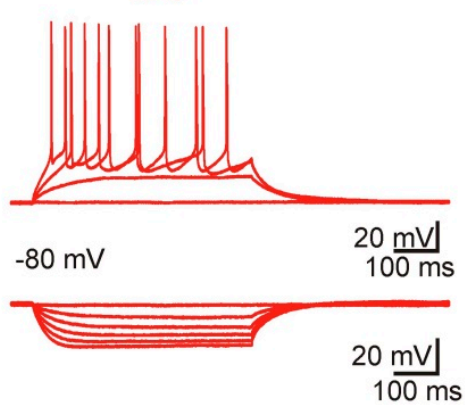

B

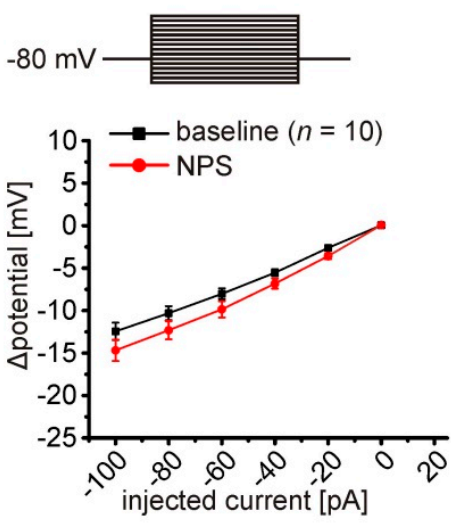

C

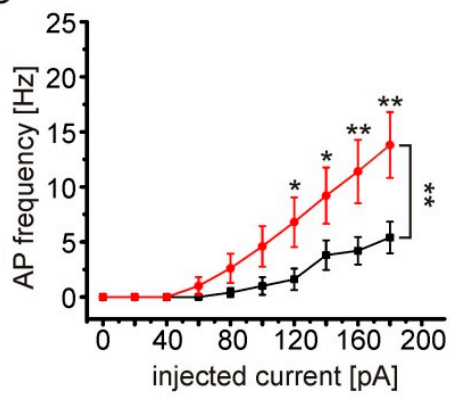

D
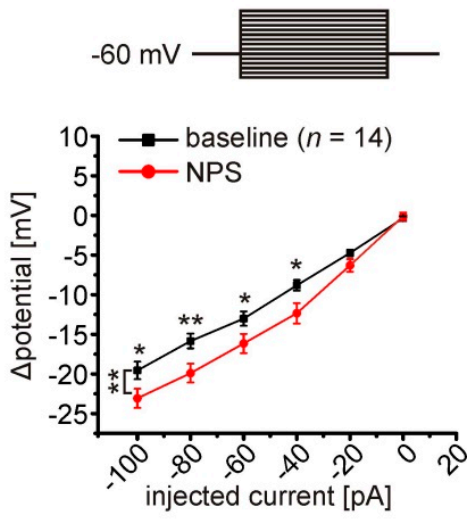

E

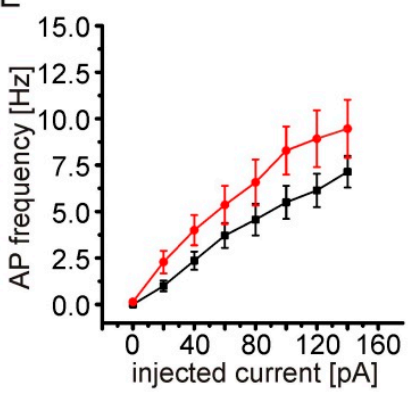

$\mathrm{F}$

\begin{tabular}{|r|c|c|c|c|} 
& \multicolumn{2}{|c|}{ Potential: $-\mathbf{8 0 ~} \mathrm{mV}$} & \multicolumn{2}{c|}{ Potential: $-60 \mathrm{mV}$} \\
\hline condition & baseline & NPS & baseline & NPS \\
\hline threshold [mV] & $\mathbf{- 4 6 . 9 \pm 0 . 8}$ & $\mathbf{- 4 8 . 7 \pm 1 . 1}$ & $-45.4 \pm 0.8$ & $-46.1 \pm 1.1$ \\
\hline Amplitude [mV] & $85.4 \pm 0.9$ & $86.4 \pm 1.1$ & $83 \pm 1.1$ & $81.5 \pm 1.4$ \\
\hline AHP [mV] & $-7.2 \pm 0.7$ & $-6.5 \pm 0.9$ & $-6.9 \pm 0.9$ & $-6.8 \pm 1.2$ \\
\hline Half-width [ms] & $1.03 \pm 0.04$ & $0.95 \pm 0.05$ & $1.01 \pm 0.03$ & $1.03 \pm 0.03$ \\
\hline
\end{tabular}

Figure 6. NPSR1-activation enhances action potential generation in aBA PNs. (A) Example of the experimental procedure. Current-clamp recordings were done during baseline conditions (black arrow) and during maximal NPS effect (red arrow). The onset of the NPS effect was monitored in voltage-clamp at $-60 \mathrm{mV}$. In current-clamp, hyper- and depolarizing current injections (first: $-100 \mathrm{pA} ; \Delta+20 \mathrm{pA} ; 500 \mathrm{~ms}$ duration) were applied from a membrane potential of either $-60 \mathrm{mV}$ or $-80 \mathrm{mV}$. Example traces depict recordings from $-80 \mathrm{mV}$ during baseline (black) or in the presence of NPS (red). (B) Analysis of passive membrane properties during current injections $(-100$ to $+50 \mathrm{pA})$ from a membrane potential of $-80 \mathrm{mV}$. No significant changes of $\Delta$ potential in response to current injections were observed in the presence of NPS. (C) Frequency of evoked action potentials is enhanced in the presence of NPS compared to baseline. (D) At $-60 \mathrm{mV}$ hyperpolarizing current injections resulted in enhanced $\Delta$ potential in the presence of NPS. (E) At $-60 \mathrm{mV}$ depolarizing current injections did not change the discharge pattern significantly. (F) Analysis of action potential characteristics during baseline conditions and in the presence of NPS during both recording conditions. ${ }^{*} p<0.05 ;{ }^{* *} p<0.01$.

\section{Discussion}

The vast majority of available studies describe the function of the NPS system on a network level [8,22], analyze behavioral consequences following pharmacological or genetic interventions $[5,9,31]$, or point out implications of NPSR1 single-nucleotide polymorphisms for psychiatric disorders in humans [32,33]. Other studies analyzed structure-function relationships of NPSR1 and NPS, using HEK or CHO expression systems and rodent models $[24,34,35]$. In contrast, little is known about signaling cascades in neurons endogenously expressing the NPSR1.

Here, we used electrophysiological approaches, combined with pharmacology, to investigate intracellular signaling and possible second messengers and effectors in principal neurons of the anterior basolateral complex of mice. Based on our data, we can (a) confirm 
the expression profile of NPSR1 mRNA in the aBA, (b) describe NPS-specific activation of the NPSR1 in aBA PNs of male and female mice, (c) provide evidence that the NPSR1mediated inward current is dependent on G $\alpha$ q signaling, (d) identify a reduction of membrane $\mathrm{K}^{+}$conductance in these neurons as consequence of NPSR1 stimulation, and (e) show NPS-induced increase in neuronal excitability.

As described previously $[3,8,24]$, high NPSR1 mRNA expression can be detected in the aBA of mice, whereas it is almost absent in the posterior BA or the central nuclei of the amygdala. NPSR1 activation by the application of NPS induced a transient inward current in about 80 to $90 \%$ of the recorded aBA PNs, which was abolished by the NPSR1-specific antagonist SHA-68 [25]. The NPSR1-mediated current was not different between males and females, in line with our previous findings documenting a lack of sex-based differences on the cellular level [24]. This inward current was accompanied by an increase in apparent input resistance, which has also been described in projection neurons of the endopiriform nucleus [22]. These findings indicate a reduction of membrane conductance, which is active at a membrane potential of $-60 \mathrm{mV}$. Analysis of current-voltage relationships of the NPS-induced current and recordings in elevated extracellular $\mathrm{K}^{+}$concentrations revealed a reversal potential near the respective $\mathrm{K}^{+}$equilibrium potential, identifying $\mathrm{K}^{+}$ions as carriers of the current. GPCRs can modulate $\mathrm{K}^{+}$channel activity through changes in channel conductance and/or open probability. For example, activation of muscarinic receptors induces G-protein-mediated negative modulation of K2P channels involving different intracellular signaling molecules $[36,37]$ in, e.g., thalamic relay neurons.

The NPSR1-mediated current requires intracellular G protein activity, as inhibition by GDP- $\beta$-S abolished the inward current. Thus, direct protein-protein interaction of the NPSR1 and a putative effector seems not to be involved. Furthermore, inhibition of the $\beta / \gamma$-subunits by gallein had no effect on the NPSR1-mediated current, leading to the conclusion that $\mathrm{G} \alpha$-signaling is mandatory. Depending on the $\alpha$-subunit involved ( $\alpha$ s and/or $\alpha q$ ), different downstream signaling molecules, such as adenylyl cyclases $\left(A C ;\right.$ by $\mathrm{G}_{\alpha \mathrm{s}}$ ) or phospholipases (PL; $\mathrm{G}_{\alpha \mathrm{q}}$ ), would be activated in prototypic pathways. Here, NPSR1-mediated currents were insensitive to AC inhibition or intracellular cAMP application, ruling out a major contribution of $G \alpha$ s signaling, which has been described to occur after NPSR1 activation in HEK or CHO cells [17,38]. In contrast, the NPSR1-mediated current in aBA PNs was strongly reduced by manipulation of intracellular $\mathrm{Ca}^{2+}$ by either BAPTA or 2-APB. Intracellular $\mathrm{Ca}^{2+}$-transients have been described in detail previously in cultured hippocampal neurons expressing human NPSR1 [19]. In these assays, 2-APB abolished the rise of intracellular $\mathrm{Ca}^{2+}$, most likely due to inhibition of IP3Rs and SOCE. In addition, in dorsal raphe (DR) and laterodorsal tegmentum (LT), NPS application induced an increase of intracellular $\mathrm{Ca}^{2+}$ involving IP3Rs and RyR [21]. Moreover, the NPSR1mediated current was also dependent on $\mathrm{Ca}^{2+}$ in DR and LT neurons. Thus, mobilization of intracellular $\mathrm{Ca}^{2+}$ as a second messenger seems to be shared by aBA PNs and DR/LT neurons following NPSR1 activation. It is interesting to note that $\mathrm{Ca}^{2+}$ release induced by PLC activation feeds back on PLC, a strong positive feedback mechanism that is sensitive to BAPTA application [39], thereby emphasizing the significance of the $G_{\alpha q} /$ PLC pathway for the present findings.

While the involvement of $\mathrm{K}^{+}$channels seems to be clear, our pharmacological assays provide some hints with respect to $\mathrm{K}^{+}$channel isoforms modulated by NPSR1, without identifying the exact types of channels involved. Results obtained with barium at the concentration used in the present study exclude the involvement of G-protein-coupled inward rectifier $\left(\mathrm{G}_{\text {irk }}\right)$ channels as potential targets. The concentration of XE991 used inhibits KV7.1/2/4, but not KV7.5, which has been shown to mediate M-type currents in various neurons of various brain regions, including BLA [40]. Overall, the NPS-evoked $\mathrm{K}^{+}$current was sensitive to intracellular TEA and 4-AP, typifying delayed rectifier and A-type $\mathrm{K}^{+}$channels. 4-AP-sensitive $\mathrm{K}^{+}$channels of the $\mathrm{KCND}$ family mediate a transient, hyperpolarization-dependent A-type current, which is thought to mediate a delayed onset of spike firing if evoked from membrane potentials negative from resting membrane poten- 
tials [41]. The lack of noticeable delayed onset of firing in our current-clamp recordings from $-80 \mathrm{mV}$ suggests that A-type currents are not prominently present in aBA PNs, and are unlikely to mediate the NPSR1-mediated current. The lack of effect of THA or PK-THPP excludes TASK channels as targets of NPSR1 signaling [42]. Taken together, these data leave members of the delayed rectifier classes and Kv7.5 as most plausible candidates. M-current mediating $\mathrm{K}_{V} 7.5$ channels are inhibited directly by intracellular $\mathrm{Ca}^{2+}$ [43] or, e.g., by A-kinase-anchoring protein AKAP150 [44] following GPCR-activation. Thus, NPSR1dependent intracellular signaling cascades, including $\mathrm{Ca}^{2+}$, could negatively modulate $\mathrm{K}_{\mathrm{V}} 7.5$ channels. Of note, we cannot completely rule out additional modulations of voltagegated $\mathrm{Ca}^{2+}$ channels in aBA PNs by NPSR1 activation $[45,46]$. Future experiments using elaborated pharmacology and/or single-cell mRNA sequencing are needed to identify the exact target channels. Delayed rectifier channels of the Kv2.1 subtype, characterized by PLC-mediated regulation, 4-AP-sensitivity, and incomplete inactivation, are promising candidates $[47,48]$.

In summary, we show that NPSR1 activation by NPS increases neuronal excitability in aBA PNs by the inhibition of voltage-gated $\mathrm{K}^{+}$channels. We provide data indicating the involvement of $\mathrm{G}_{\alpha q^{-}}$and intracellular calcium signaling in these neurons. As a functional consequence, NPS release in aBA will increase local network activity and can thereby modulate information processing in emotion-relevant circuits between aBA and the posterior BA (pBA), as shown before $[24,49,50]$.

Thus, the NPS/NPSR1 system is apt to shape emotional states in response to aversive stimuli and to modulate threat responses during expression of learned fear and fear extinction $[7,8,24]$. In turn, alterations of NPSR1 signaling efficacy by nonsynonymous mutations in the NPSR1 $[24,32,33,51]$ or the NPS gene [51] might consequently alter behavior and the risk for the development of psychiatric disorders. It is evident that detailed knowledge about neuropeptide systems and underlying signaling cascades is important to understand their impact on the development of psychiatric disorders. An increasing number of different neuropeptide systems (e.g., galanin, cholecystokinin, and NPY) have been shown to modulate fear [52-55] and anxiety [56-58] in rodents and humans [59]. In this respect, it is interesting to note that orexin, an excitatory neuropeptide with well-described roles in regulation of arousal and energy homeostasis, was recently found to modulate fear responses [60]. The pathway underlying in this modulation involved the PLC-dependent depolarization of neurons in the central nucleus of the amygdala, thereby pointing to some similarities in neuropeptide signaling pathways and the in vivo relevance of their modulatory influence. Therefore, detailed analysis of GPCR signaling, effects of humanrelevant polymorphisms in neuropeptide systems, and the interplay between different neuropeptide systems is needed to understand and possibly treat psychiatric diseases.

\section{Materials and Methods}

All animal experiments were carried out in accordance with European regulations on animal experimentation (European Committee Council Directive 2010/63/EU; National Research Council of the National Academies), and approved by the local authorities (LANUV).

\subsection{Animals}

C57BL $/ 6 \mathrm{~N}$ were kept in a temperature-controlled $\left(21^{\circ} \mathrm{C}\right)$ and humidity-controlled (50-60\% relative humidity) animal facility in individually ventilated cages, with access to food and water ad libitum and a $12 \mathrm{~h} \mathrm{light/dark} \mathrm{cycle,} \mathrm{with} \mathrm{lights} \mathrm{on} \mathrm{at} \mathrm{6:00} \mathrm{am.} \mathrm{Food,}$ water, and animal conditions were controlled on a daily basis. For experiments, male and female mice 6 to 8 weeks of age were used.

\subsection{Electrophysiology}

Experimental procedures were carried out as described previously [24]. Mice were decapitated, and brains were quickly removed. Coronal or horizontal brain slices (300 $\mu \mathrm{m}$ thickness), containing the amygdala, were cut on a vibratome (VT1200S; Leica, Germany). 
Slices were placed in a submersion chamber at $30{ }^{\circ} \mathrm{C}$ and were perfused with artificial CSF (ACSF) containing the following (in mM): $120 \mathrm{NaCl}, 2.5 \mathrm{KCl}, 1.25 \mathrm{NaH}_{2} \mathrm{PO}_{4}, 2 \mathrm{MgSO}_{4}$, $2 \mathrm{CaCl}_{2}, 22 \mathrm{NaHCO}_{3}$, and 20 glucose. The $\mathrm{pH}$ was set to 7.35 by gassing with carbogen. Perfusion speed was set to $3.5-4 \mathrm{~mL} / \mathrm{min}$.

Patch pipettes (2.5-4 M $\Omega$ pipette resistance) were made of borosilicate glass (GC150T10; Harvard Apparatus, Holliston, MA, USA). The intracellular solution contained the following (in $\mathrm{mM}$ ): $10 \mathrm{NaCl}, 105$ potassium gluconate, 20 potassium citrate, $10 \mathrm{HEPES}$, 3 BAPTA, $0.5 \mathrm{CaCl}_{2}, 1 \mathrm{MgCl}_{2}, 3 \mathrm{MgATP}, 0.5 \mathrm{NaGTP}$, and 15 phosphocreatine, $\mathrm{pH}$ adjusted to 7.25. The liquid junction potential of $10 \mathrm{mV}$ was compensated online. In some experiments, a $\mathrm{Cs}^{+}$-based intracellular solution was used, containing (mM): 54 -aminopyridine, $120 \mathrm{CsMeSO}_{4}, 1$ EGTA, 10 HEPES, 20 tetraethylammonium chloride, $2 \mathrm{MgCl}_{2}, 0.5 \mathrm{CaCl}_{2}$, 2 Na-ATP, and $0.5 \mathrm{Na}$ GTP. To analyze NPS-induced currents, aBA principal neurons (PN) were recorded in the voltage-clamp mode at a membrane potential of $-60 \mathrm{mV}$. Neurons were recorded for at least $15 \mathrm{~min}$. Every $10 \mathrm{~s}$, a voltage-step of $-5 \mathrm{mV}$ was used to monitor the apparent input resistance. To reduce network activity, the ACSF contained: tetrodotoxin citrate (TTX; $0.5 \mu \mathrm{M}$; Abcam, Cambridge, UK), 6,7-dinitroquinoxaline-2,3-dione disodium salt (DNQX; $10 \mu \mathrm{M}$; Abcam), DL-2-amino-5-phosphonopentanoic acid sodium salt (AP5; $25 \mu \mathrm{M}$; Abcam), 2-(3-carboxypropyl)-3-amino-6-(4 methoxyphenyl)pyridazinium bromide (gabazine; $10 \mu \mathrm{M}$; Abcam), and (2S)-3-[((1S)-1-(3,4-dichlorophenyl)ethyl)-amino-2hydroxypropyl]-(phenylmethyl)phosphinic acid hydrochloride (CGP55845; $2.5 \mu \mathrm{M}$; Tocris). NPS (50 or $150 \mathrm{nM}$; Tocris, Bristol, UK) was bath-applied for $2.5 \mathrm{~min}$. The recorded current was normalized to the capacitance of the $\mathrm{PN}$ and is presented as current density $(\mathrm{pA} / \mathrm{pF})$ to correct for differences in PN size. Recorded aBA PNs were sorted into responsive and nonresponsive by statistical comparison (paired $t$-test) of current densities during baseline, with current densities in a 2.5 min time window after NPS application. If not stated otherwise, only responsive PNs were analyzed. In total, four sets of control recordings were obtained. Pharmacological interventions are compared to the respective set of control recordings.

Voltage-clamp step protocols were performed from a holding potential of $-60 \mathrm{mV}$, and steps from $-120 \mathrm{mV}$ to $-50 \mathrm{mV}(\Delta+10 \mathrm{mV})$ were applied for two seconds each. Resultant current traces during baseline and in the presence of NPS were subtracted (current ${ }_{\mathrm{NPS}}{ }^{-}$ current $_{\text {baseline }}$ ) to calculate the NPS-induced (NPSR1-mediated) current. The reversal potential of the NPS-induced current was calculated for each individual PN. Hyperpolarizing voltageclamp ramps were done from a step to $0 \mathrm{mV}(1 \mathrm{~s})$ to $-120 \mathrm{mV}$ (ramp velocity: $0.48 \mathrm{mV} / \mathrm{ms}$ ). The NPS-induced current was calculated from ramp NPS $_{\text {and }}$ ramp baseline, analyzed as described above. Substances for pharmacological interventions: $n$-[((4-fluorophenyl)methyl)tetrahydro3-oxo-1,1-diphenyl-3H-oxazolo(3,4-a)]pyrazine-7 (1H)-carboxamide (SHA-68; $10 \mu \mathrm{M}$; Tocris, Bristol, UK), GDP- $\beta-S$ trilithium salt (2 mM; Sigma Aldrich, St. Louis, MO, USA), 3' $3^{\prime} 4^{\prime}, 5^{\prime}, 6^{\prime}-$ tetrahydroxyspiro[isobenzofuran-1(3H), $9^{\prime}$-(9H)xanthen]-3-one (Gallein; $50 \mu \mathrm{M}$, Tocris), 1,2bis(2-aminophenoxy)ethane- $\mathrm{N}, \mathrm{N}, \mathrm{N}^{\prime}, \mathrm{N}^{\prime}$-tetraacetic acid (BAPTA, $10 \mathrm{mM}$, Sigma Aldrich, St. Louis, MO, USA); 2-aminoethoxydiphenylborate (2-APB; $50 \mu \mathrm{M}$; Sigma Aldrich, St. Louis, MO, USA), 8-bromoadenosine $3^{\prime}, 5^{\prime}$-cyclic monophosphate sodium salt (8-Br-cAMP; $100 \mu \mathrm{M}$; Sigma Aldrich, St. Louis, MO, USA), 9-(tetrahydro-2-furanyl)-9H-purin-6-amine (SQ 22536; $90 \mu \mathrm{M}$; Tocris, Bristol, UK), 10,10-bis(4-pyridinylmethyl)-9(10H)-anthracenone dihydrochloride (XE991; $20 \mu \mathrm{M}$; Tocris, Bristol, UK), tetraethylammonium chloride (TEA; $10 \mathrm{mM}$; Sigma Aldrich, St. Louis, MO, USA), 4-aminopyridine (4-AP; 10 mM; Sigma Aldrich, St. Louis, MO, USA), tetrahexylammonium chloride (THA; $10 \mu \mathrm{M}$; St. Louis, MO, USA), 1-[1-[6-((1,1'-biphenyl)4-ylcarbonyl)-5,6,7,8-tetrahydropyrido(4,3-d)pyrimidin-4-yl]-4-piperidinyl]-1-butanone (PKTHPP; $1 \mu \mathrm{M}$; Tocris, Bristol, UK). To inhibit adenylyl cyclases, slices were preincubated in ACSF containing SQ 22536 for $>1 \mathrm{~h}$, and SQ 22536 was included in the pipette during subsequent recordings. The concentration of the anorganic solvent dimethylsulfoxide (DMSO) was kept below $0.02 \%$ when present. DMSO alone at the concentration used did not interfere with the observed NPSR1-mediated current. 
Hyper- and depolarizing current injections (500 ms duration; $\Delta+20 \mathrm{pA}$ ) were performed in the current-clamp mode at membrane potentials of -60 and $-80 \mathrm{mV}$. For current-voltage relationships, shifts of the membrane potential ( $\Delta$ potential) in response to hyperpolarizing current were analyzed. NPS was applied at a concentration of $150 \mathrm{nM}$, and the onset of the NPS-induced inward current was monitored in voltage-clamp mode. All electrophysiological recordings were performed using a HEKA 10 double patch clamp amplifier and PatchMaster software.

\subsection{RNAScope}

RNAScope (ACD Biotechne, Newark, CA, USA) was used to detect Npsr1 mRNA in aBA neurons via fluorescence in situ hybridization. All steps were performed according to the manufacturer's instructions. Coronal sections containing the amygdala were prepared from fresh frozen brain tissue. Detection of Npsr1 mRNA was performed in $16 \mu \mathrm{m}$ thick fresh frozen coronal slices of, in total, two animals, using RNAScope Multiplex-Fluorescent assay kit with predesigned probes for mouse Npsr1. Stained specimens were covered with Vectashield mounting medium (Vector Laboratories, Burlingame, CA, USA) and analyzed using a confocal microscope (Nikon, Minato, Japan) with appropriate objectives and filter sets (DAPI: 450/35; Alexa488: 515/30; Atto550: 605/75). Image stacks (7 $\mu \mathrm{m}$ z-axis; $1 \mu \mathrm{m}$ steps) were acquired $(1024 \times 1024$ resolution) using an Achromat 16.0 x/0.80/3.00 NCG Water Dip objective. Image stacks were processed with ImageJ 1.52p (Wayne Rasband, National Institute of Health, Bethesda, MD, USA). Using maximum z-projection, stacks were merged into a 2D picture.

\subsection{Analysis and Statistics}

All datasets were retrieved from neurons of at least three mice. The number of experiments " $n$ " represents the number of analyzed neurons. Electrophysiological recordings were analyzed offline using Clampfit 10.5 (Molecular Devices, San Jose, CA, USA). Statistical analysis was done with Origin 9.1 (Origin Lab Corporation, Northampton, MA, USA) and Statistica 64 (Tibco Software Inc., Palo Alto, CA, USA). All final datasets were tested once for statistical outliers using Grubb's test, and identified values were removed. Statistical comparison was done using either Student's $t$-test or Mann-Whitney U-test, depending on normal or non-normal data distribution. One-way ANOVA or repeated measurements ANOVA (RM-ANOVA) were used and Bonferroni or Fisher's LSD post hoc tests were applied as indicated. CorelDraw X4 (Corel Coperation, Ottawa, ON, Canada) was used for data presentation. Statistically significant differences are presented as: ${ }^{*} p<0.05$; ** $p<0.01$.

Author Contributions: K.J. and H.-C.P. conceptualized the study. S.P., P.F., C.W., H.M.S., L.G. and K.J. performed the in vitro electrophysiological experiments, and analyzed the data. H.M.S. performed RNAScope. K.J., T.B. and H.-C.P. wrote the paper. All authors have read and agreed to the published version of the manuscript.

Funding: This project has been funded by the German Research Foundation (DFG; Grant: CRC TRR58 TP A07 to K.J., TP A03 to H.C.P.).

Institutional Review Board Statement: All animal experiments were carried out in accordance with European regulations on animal experimentation (European Committee Council Directive 2010/63/EU; National Research Council of the National Academies), approved by the local authorities (LANUV).

Informed Consent Statement: Not applicable.

Data Availability Statement: The data presented in this study are available on request from the corresponding author.

Acknowledgments: We would like to thank Elke Nass, Birgit Herrenpoth, Angelika Klinge, Katrin Foraita, and Alexandra Markovic for excellent technical assistance. We gratefully thank Peter Blaesse for critically reading the manuscript. 
Conflicts of Interest: The authors declare no conflict of interest.

\section{References}

1. Xu, Y.-L.; Reinscheid, R.K.; Huitron-Resendiz, S.; Clark, S.D.; Wang, Z.; Lin, S.H.; Brucher, F.A.; Zeng, J.; Ly, N.K.; Henriksen, S.J.; et al. Neuropeptide S: A neuropeptide promoting arousal and anxiolytic-like effects. Neuron 2004, 43, 487-497. [CrossRef]

2. Adori, C.; Barde, S.; Bogdanovic, N.; Uhlén, M.; Reinscheid, R.R.; Kovacs, G.G.; Hökfelt, T. Neuropeptide S- and Neuropeptide S receptor-expressing neuron populations in the human pons. Front. Neuroanat. 2015, 9, 126. [CrossRef]

3. Clark, S.D.; Duangdao, D.M.; Schulz, S.; Zhang, L.; Liu, X.; Xu, Y.-L.; Reinscheid, R.K. Anatomical characterization of the neuropeptide $\mathrm{S}$ system in the mouse brain by in situ hybridization and immunohistochemistry. J. Comp. Neurol. 2011, 519, 1867-1893. [CrossRef] [PubMed]

4. Liu, X.; Zeng, J.; Zhou, A.; Theodorsson, E.; Fahrenkrug, J.; Reinscheid, R.K. Molecular fingerprint of neuropeptide s-producing neurons in the mouse brain. J. Comp. Neurol. 2011, 519, 1847-1866. [CrossRef] [PubMed]

5. Liu, X.; Si, W.; Garau, C.; Jüngling, K.; Pape, H.C.; Schulz, S.; Reinscheid, R.K. Neuropeptide S precursor knockout mice display memory and arousal deficits. Eur. J. Neurosci. 2017, 46, 1689-1700. [CrossRef] [PubMed]

6. Okamura, N.; Garau, C.; Duangdao, D.M.; Clark, S.D.; Jüngling, K.; Pape, H.C.; Reinscheid, R.K. Neuropeptide S enhances memory during the consolidation phase and interacts with noradrenergic systems in the brain. Neuropsychopharmacology 2011, 36, 744-752. [CrossRef] [PubMed]

7. Jüngling, K.; Lange, M.D.; Szkudlarek, H.J.; Lesting, J.; Erdmann, F.S.; Doengi, M.; Kügler, S.; Pape, H.-C. Increased GABAergic Efficacy of Central Amygdala Projections to Neuropeptide S Neurons in the Brainstem During Fear Memory Retrieval. Neuropsychopharmacology 2015, 40, 2753-2763. [CrossRef]

8. Jüngling, K.; Seidenbecher, T.; Sosulina, L.; Lesting, J.; Sangha, S.; Clark, S.D.; Okamura, N.; Duangdao, D.M.; Xu, Y.L.; Reinscheid, R.K.; et al. Neuropeptide S-Mediated Control of Fear Expression and Extinction: Role of Intercalated GABAergic Neurons in the Amygdala. Neuron 2008, 59, 298-310. [CrossRef]

9. Fendt, M.; Imobersteg, S.; Bürki, H.; McAllister, K.H.; Sailer, A.W. Intra-amygdala injections of neuropeptide S block fearpotentiated startle. Neurosci. Lett. 2010, 474, 154-157. [CrossRef]

10. Germer, J.; Kahl, E.; Fendt, M. Memory generalization after one-trial contextual fear conditioning: Effects of sex and neuropeptide S receptor deficiency. Behav. Brain Res. 2019, 361, 159-166. [CrossRef] [PubMed]

11. Grund, T.; Neumann, I.D. Brain neuropeptide S: Via GPCR activation to a powerful neuromodulator of socio-emotional behaviors. Cell Tissue Res. 2019, 375, 123-132. [CrossRef] [PubMed]

12. Ruggeri, B.; Braconi, S.; Cannella, N.; Kallupi, M.; Soverchia, L.; Ciccocioppo, R.; Ubaldi, M. Neuropeptide S receptor gene expression in alcohol withdrawal and protracted abstinence in postdependent rats. Alcohol. Clin. Exp. Res. 2010. [CrossRef]

13. Kallupi, M.; Cannella, N.; Economidou, D.; Ubaldi, M.; Ruggeri, B.; Weiss, F.; Massi, M.; Marugan, J.; Heilig, M.; Bonnavion, P.; et al. Neuropeptide $S$ facilitates cue-induced relapse to cocaine seeking through activation of the hypothalamic hypocretin system. Proc. Natl. Acad. Sci. USA 2010. [CrossRef] [PubMed]

14. Fisyunov, A.I. Molecular mechanisms of G protein-independent signaling mediated by 7-transmembrane receptors. Neurophysiology 2012, 44, 255-264. [CrossRef]

15. Hilger, D.; Masureel, M.; Kobilka, B.K. Structure and dynamics of GPCR signaling complexes. Nat. Struct. Mol. Biol. 2018, 25, 4-12. [CrossRef] [PubMed]

16. Roth, A.L.; Marzola, E.; Rizzi, A.; Arduin, M.; Trapella, C.; Corti, C.; Vergura, R.; Martinelli, P.; Salvadori, S.; Regoli, D.; et al. Structure-activity studies on neuropeptide S: Identification of the amino acid residues crucial for receptor activation. J. Biol. Chem. 2006. [CrossRef]

17. Reinscheid, R.K.; Xu, Y.-L.; Okamura, N.; Zeng, J.; Chung, S.; Pai, R.; Wang, Z.; Civelli, O. Pharmacological Characterization of Human and Murine Neuropeptide S Receptor Variants. J. Pharmacol. Exp. Ther. 2005, 315, 1338-1345. [CrossRef] [PubMed]

18. Liao, Y.; Lu, B.; Ma, Q.; Wu, G.; Lai, X.; Zang, J.; Shi, Y.; Liu, D.; Han, F.; Zhou, N. Human Neuropeptide S Receptor Is Activated via a G $\propto$ q Protein-biased Signaling Cascade by a Human Neuropeptide S Analog Lacking the C-terminal 10 Residues. J. Biol. Chem. 2016, 291, 7505-7516. [CrossRef]

19. Erdmann, F.; Kügler, S.; Blaesse, P.; Lange, M.D.; Skryabin, B.V.; Pape, H.C.; Jüngling, K. Neuronal expression of the human neuropeptideS receptor NPSR1 identifies NPS-induced calcium signaling pathways. PLoS ONE 2015, 10, e0117319. [CrossRef]

20. Grund, T.; Goyon, S.; Li, Y.; Eliava, M.; Liu, H.; Charlet, A.; Grinevich, V.; Neumann, I.D. Neuropeptide S Activates Paraventricular Oxytocin Neurons to Induce Anxiolysis. J. Neurosci. 2017, 37, 12214-12225. [CrossRef] [PubMed]

21. Roncacè, V.; Polli, F.S.; Zojicic, M.; Kohlmeier, K.A. Neuropeptide S (NPS) is a neuropeptide with cellular actions in arousal and anxiety-related nuclei: Functional implications for effects of NPS on wakefulness and mood. Neuropharmacology 2017. [CrossRef]

22. Meis, S.; Bergado-Acosta, J.R.; Yanagawa, Y.; Obata, K.; Stork, O.; Munsch, T. Identification of a Neuropeptide S Responsive Circuitry Shaping Amygdala Activity via the Endopiriform Nucleus. PLoS ONE 2008, 3, e2695. [CrossRef] [PubMed]

23. Meis, S.; Munsch, T.; Sosulina, L.; Pape, H.C. Postsynaptic mechanisms underlying responsiveness of amygdaloid neurons to cholecystokinin are mediated by a transient receptor potential-like current. Mol. Cell. Neurosci. 2007, 35, 356-367. [CrossRef] 
24. Bengoetxea, X.; Goedecke, L.; Remmes, J.; Blaesse, P.; Grosch, T.; Lesting, J.; Pape, H.C.; Jüngling, K. Human-specific neuropeptide $\mathrm{S}$ receptor variants regulate fear extinction in the basal amygdala of male and female mice depending on threat salience. Biol. Psychiatry 2021. [CrossRef] [PubMed]

25. Okamura, N.; Habay, S.A.; Zeng, J.; Chamberlin, A.R.; Reinscheid, R.K. Synthesis and pharmacological in vitro and in vivo profile of 3-oxo-1,1-diphenyl-tetrahydro-oxazolo[3,4-a]pyrazine-7-carboxylic acid 4-fluoro-benzylamide (SHA 68), a selective antagonist of the neuropeptide S receptor. J. Pharmacol. Exp. Ther. 2008, 325, 893-901. [CrossRef]

26. Suh, B.C.; Horowitz, L.F.; Hirdes, W.; Mackie, K.; Hille, B. Regulation of KCNQ2/KCNQ3 current by G protein cycling: The kinetics of receptor-mediated signaling by Gq. J. Gen. Physiol. 2004. [CrossRef]

27. Bootman, M.D.; Collins, T.J.; Mackenzie, L.; Roderick, H.L.; Berridge, M.J.; Peppiatt, C.M. 2-Aminoethoxydiphenyl borate (2-APB) is a reliable blocker of store-operated Ca $2+$ entry but an inconsistent inhibitor of InsP 3 -induced Ca $2+$ release. FASEB J. 2002. [CrossRef]

28. Maruyama, T.; Kanaji, T.; Nakade, S.; Kanno, T.; Mikoshiba, K. 2APB, 2-aminoethoxydiphenyl borate, a membrane-penetrable modulator of Ins $(1,4,5) \mathrm{P} 3$-induced Ca2+ release. J. Biochem. 1997. [CrossRef]

29. Togashi, K.; Inada, H.; Tominaga, M. Inhibition of the transient receptor potential cation channel TRPM2 by 2-aminoethoxydiphenyl borate (2-APB). Br. J. Pharmacol. 2008. [CrossRef]

30. Braas, K.M.; May, V. Pituitary adenylate cyclase-activating polypeptides directly stimulate sympathetic neuron neuropeptide Y release through PAC1 receptor isoform activation of specific intracellular signaling pathways. J. Biol. Chem. 1999, 274, 27702-27710. [CrossRef] [PubMed]

31. Kreutzmann, J.C.; Khalil, R.; Köhler, J.C.; Mayer, D.; Florido, A.; Nadal, R.; Andero, R.; Fendt, M. Neuropeptide-S-receptor deficiency affects sex-specific modulation of safety learning by pre-exposure to electric stimuli. Genes Brain Behav. 2020. [CrossRef]

32. Okamura, N.; Hashimoto, K.; Iyo, M.; Shimizu, E.; Dempfle, A.; Friedel, S.; Reinscheid, R.K. Gender-specific association of a functional coding polymorphism in the Neuropeptide $S$ receptor gene with panic disorder but not with schizophrenia or attention-deficit/hyperactivity disorder. Prog. Neuro-Psychopharmacol. Biol. Psychiatry 2007, 31, 1444-1448. [CrossRef]

33. Domschke, K.; Reif, A.; Weber, H.; Richter, J.; Hohoff, C.; Ohrmann, P.; Pedersen, A.; Bauer, J.; Suslow, T.; Kugel, H.; et al. Neuropeptide $S$ receptor gene - converging evidence for a role in panic disorder. Mol. Psychiatry 2011, 16, 938-948. [CrossRef]

34. Clark, S.D.; Tran, H.T.; Zeng, J.; Reinscheid, R.K. Importance of extracellular loop one of the neuropeptide S receptor for biogenesis and function. Peptides 2010, 31, 130-138. [CrossRef] [PubMed]

35. Camarda, V.; Ruzza, C.; Rizzi, A.; Trapella, C.; Guerrini, R.; Reinscheid, R.K.; Calo, G. In vitro and in vivo pharmacological characterization of the novel neuropeptide $S$ receptor ligands QA1 and PI1. Peptides 2013, 48, 27-35. [CrossRef] [PubMed]

36. Bista, P.; Pawlowski, M.; Cerina, M.; Ehling, P.; Leist, M.; Meuth, P.; Aissaoui, A.; Borsotto, M.; Heurteaux, C.; Decher, N.; et al . Differential phospholipase C-dependent modulation of TASK and TREK two-pore domain K+ channels in rat thalamocortical relay neurons. J. Physiol. 2015, 593, 127-144. [CrossRef]

37. Chen, X.; Talley, E.M.; Patel, N.; Gomis, A.; McIntire, W.E.; Dong, B.; Viana, F.; Garrison, J.C.; Bayliss, D.A. Inhibition of a background potassium channel by Gq protein $\alpha$-subunits. Proc. Natl. Acad. Sci. USA 2006, 103, 3422-3427. [CrossRef]

38. Pape, H.-C.; Jüngling, K.; Seidenbecher, T.; Lesting, J.; Reinscheid, R.K. Neuropeptide S: A transmitter system in the brain regulating fear and anxiety. Neuropharmacology 2010, 58, 29-34. [CrossRef]

39. Horowitz, L.F.; Hirdes, W.; Suh, B.C.; Hilgemann, D.W.; Mackie, K.; Hille, B. Phospholipase C in living cells: Activation, inhibition, $\mathrm{Ca} 2+$ requirement, and regulation of M current. J. Gen. Physiol. 2005, 126, 243-262. [CrossRef] [PubMed]

40. Schroeder, B.C.; Hechenberger, M.; Weinreich, F.; Kubisch, C.; Jentsch, T.J. KCNQ5, a Novel Potassium Channel Broadly Expressed in Brain, Mediates M-type Currents. J. Biol. Chem. 2000, 275, 24089-24095. [CrossRef]

41. Fransén, E.; Tigerholm, J. Role of A-type potassium currents in excitability, network synchronicity, and epilepsy. Hippocampus 2010, 20, 877-887. [CrossRef] [PubMed]

42. Ramírez, D.; Bedoya, M.; Kiper, A.K.; Rinné, S.; Morales-Navarro, S.; Hernández-Rodríguez, E.W.; Sepúlveda, F.V.; Decher, N.; González, W. Structure/activity analysis of task-3 channel antagonists based on a 5,6,7,8 tetrahydropyrido[4,3-d]pyrimidine. Int. J. Mol. Sci. 2019, 20, 2252. [CrossRef] [PubMed]

43. Selyanko, A.A.; Brown, D.A. Intracellular calcium directly inhibits potassium $\mathrm{M}$ channels in excised membrane patches from rat sympathetic neurons. Neuron 1996, 16, 151-162. [CrossRef]

44. Hoshi, N.; Zhang, J.S.; Omaki, M.; Takeuchi, T.; Yokoyama, S.; Wanaverbecq, N.; Langeberg, L.K.; Yoneda, Y.; Scott, J.D.; Brown, D.A.; et al. AKAP150 signaling complex promotes suppression of the M-current by muscarinic agonists. Nat. Neurosci. 2003, 6, 564-571. [CrossRef] [PubMed]

45. Altier, C. GPCR and voltage-gated calcium channels (VGCC) signaling complexes. Subcell. Biochem. 2012, 63, $241-262$. [CrossRef] [PubMed]

46. Huang, J.; Zamponi, G.W. Regulation of voltage gated calcium channels by GPCRs and post-translational modification. Curr. Opin. Pharmacol. 2017, 32, 1-8. [CrossRef]

47. Kirsch, G.E.; Drewe, J.A. Gating-dependent mechanism of 4-aminopyridine block in two related potassium channels. J. Gen. Physiol. 1993. [CrossRef] [PubMed]

48. Delgado-Ramírez, M.; De Jesús-Pérez, J.J.; Aréchiga-Figueroa, I.A.; Arreola, J.; Adney, S.K.; Villalba-Galea, C.A.; Logothetis, D.E.; Rodríguez-Menchaca, A.A. Regulation of Kv2.1 channel inactivation by phosphatidylinositol 4,5-bisphosphate. Sci. Rep. 2018, 8, 1-13. [CrossRef] 
49. Kim, J.; Pignatelli, M.; Xu, S.; Itohara, S.; Tonegawa, S. Antagonistic negative and positive neurons of the basolateral amygdala. Nat. Neurosci. 2016, 19, 1636-1646. [CrossRef]

50. Zhang, X.; Kim, J.; Tonegawa, S. Amygdala Reward Neurons Form and Store Fear Extinction Memory. bioRxiv 2019, 615096. [CrossRef]

51. Reinscheid, R.K.; Mafessoni, F.; Lüttjohann, A.; Jüngling, K.; Pape, H.C.; Schulz, S. Neandertal introgression and accumulation of hypomorphic mutations in the neuropeptide S (NPS) system promote attenuated functionality. Peptides 2021, 138. [CrossRef]

52. Tasan, R.O.; Verma, D.; Wood, J.; Lach, G.; Hörmer, B.; de Lima, T.C.M.; Herzog, H.; Sperk, G. The role of Neuropeptide Y in fear conditioning and extinction. Neuropeptides 2016, 55, 111-126. [CrossRef] [PubMed]

53. Bartsch, J.C.; Jamil, S.; Remmes, J.; Verma, D.; Pape, H.C. Functional deletion of neuropeptide Y receptors type 2 in local synaptic networks of anteroventral BNST facilitates recall and increases return of fear. Mol. Psychiatry 2020. [CrossRef] [PubMed]

54. Pomrenze, M.B.; Giovanetti, S.M.; Maiya, R.; Gordon, A.G.; Kreeger, L.J.; Messing, R.O. Dissecting the Roles of GABA and Neuropeptides from Rat Central Amygdala CRF Neurons in Anxiety and Fear Learning. Cell Rep. 2019, 29, 13-21.e4. [CrossRef] [PubMed]

55. Sanford, C.A.; Soden, M.E.; Baird, M.A.; Miller, S.M.; Schulkin, J.; Palmiter, R.D.; Clark, M.; Zweifel, L.S. A Central Amygdala CRF Circuit Facilitates Learning about Weak Threats. Neuron 2017, 93, 164-178. [CrossRef] [PubMed]

56. Locker, F.; Bieler, L.; Nowack, L.M.F.; Leitner, J.; Brunner, S.M.; Zaunmair, P.; Kofler, B.; Couillard-Despres, S. Involvement of Neuropeptide Galanin Receptors 2 and 3 in Learning, Memory and Anxiety in Aging Mice. Molecules 2021, 26, 1978. [CrossRef]

57. Brunner, S.M.; Farzi, A.; Locker, F.; Holub, B.S.; Drexel, M.; Reichmann, F.; Lang, A.A.; Mayr, J.A.; Vilches, J.J.; Navarro, X.; et al. GAL3 receptor KO mice exhibit an anxietylike phenotype. Proc. Natl. Acad. Sci. USA 2014, 111, 7138-7143. [CrossRef] [PubMed]

58. Bowers, M.E.; Choi, D.C.; Ressler, K.J. Neuropeptide regulation of fear and anxiety: Implications of cholecystokinin, endogenous opioids, and neuropeptide Y. Physiol. Behav. 2012, 107, 699-710. [CrossRef] [PubMed]

59. Ressler, K.J.; Mercer, K.B.; Bradley, B.; Jovanovic, T.; Mahan, A.; Kerley, K.; Norrholm, S.D.; Kilaru, V.; Smith, A.K.; Myers, A.J.; et al. Post-traumatic stress disorder is associated with PACAP and the PAC1 receptor. Nature 2011, 470, 492-497. [CrossRef]

60. Dustrude, E.T.; Caliman, I.F.; Bernabe, C.S.; Fitz, S.D.; Grafe, L.A.; Bhatnagar, S.; Bonaventure, P.; Johnson, P.L.; Molosh, A.I.; Shekhar, A. Orexin Depolarizes Central Amygdala Neurons via Orexin Receptor 1, Phospholipase C and Sodium-Calcium Exchanger and Modulates Conditioned Fear. Front. Neurosci. 2018, 12, 934. [CrossRef] [PubMed] 